\title{
Orthodontic treatment for prominent upper front teeth in children (Review)
}

\author{
Harrison JE, O'Brien KD, Worthington HV
}

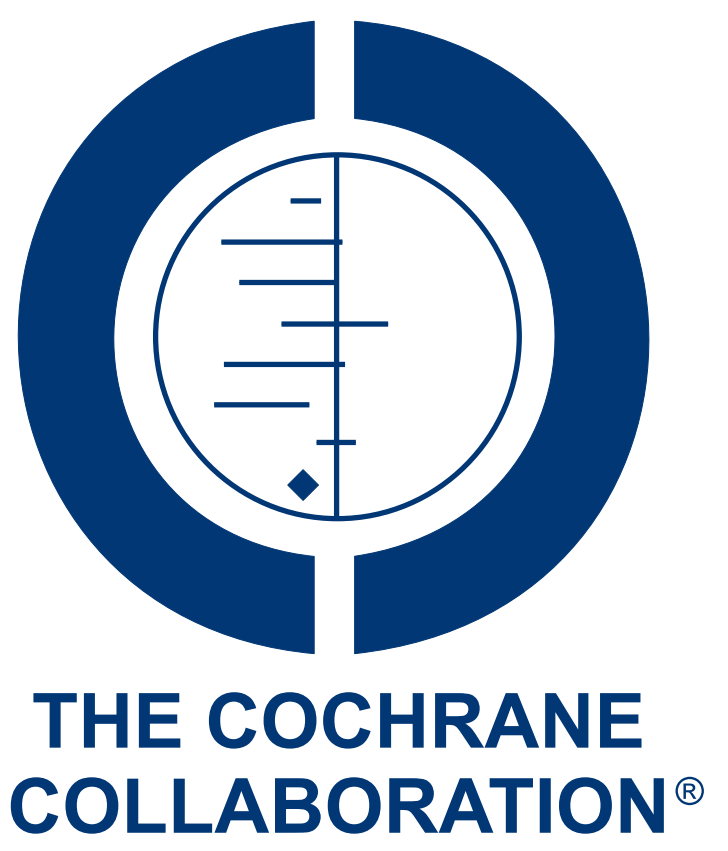

This is a reprint of a Cochrane review, prepared and maintained by The Cochrane Collaboration and published in The Cochrane Library 2009, Issue 4

http://www.thecochranelibrary.com

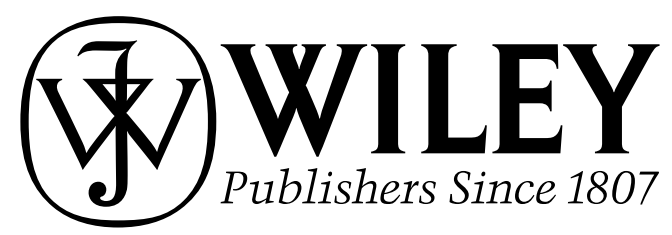

Orthodontic treatment for prominent upper front teeth in children (Review)

Copyright $\odot 2009$ The Cochrane Collaboration. Published by John Wiley \& Sons, Ltd. 
TABLE OF CONTENTS

HEADER . . . . . . . . . . . . . . . . . . . . . . . . . . . . . . . . 1

ABSTRACT .. . . . . . . . . . . . . . . . . . . . . . . . . . . . . . . . . . . . . . . . . . . . . . . . .

PLAIN LANGUAGE SUMMARY . . . . . . . . . . . . . . . . . . . . . . . . . . . . . . . . . . . . . 2

BACKGROUND . . . . . . . . . . . . . . . . . . . . . . . . . . . . . . . . . . . . 3

OBJECTIVES . . . . . . . . . . . . . . . . . . . . . . . . . . . . . . . . . . . . . . . .

METHODS . . . . . . . . . . . . . . . . . . . . . . . . . . . . . . . . . . . . . .

RESULTS . . . . . . . . . . . . . . . . . . . . . . . . . . . . . . . . . . . . . . . 5

DISCUSSION . . . . . . . . . . . . . . . . . . . . . . . . . . . . . . . . . . . . . . . . . . . . .

AUTHORS' CONCLUSIONS . . . . . . . . . . . . . . . . . . . . . . . . . . . . . . . . . . . . . . . . 8

ACKNOWLEDGEMENTS . . . . . . . . . . . . . . . . . . . . . . . . . . . . . . . . 8

REFERENCES . . . . . . . . . . . . . . . . . . . . . . . . . . . . . . . . . . . . . . . . 8

CHARACTERISTICS OF STUDIES . . . . . . . . . . . . . . . . . . . . . . . . . . . . . . . . . . . . . . 12

DATA AND ANALYSES . . . . . . . . . . . . . . . . . . . . . . . . . . . . . . . . . . 20

Analysis 1.1. Comparison 1 Early treatment at the end of Phase I: functional versus control, Outcome 1 Final overjet. 22

Analysis 1.2. Comparison 1 Early treatment at the end of Phase I: functional versus control, Outcome 2 Final ANB. 23

Analysis 1.3. Comparison 1 Early treatment at the end of Phase I: functional versus control, Outcome 3 PAR score. . 23

Analysis 1.4. Comparison 1 Early treatment at the end of Phase I: functional versus control, Outcome 4 ANB change. 24

Analysis 1.5. Comparison 1 Early treatment at the end of Phase I: functional versus control, Outcome 5 Self concept. 24

Analysis 1.6. Comparison 1 Early treatment at the end of Phase I: functional versus control, Outcome 6 Incidence of incisal trauma during Phase I treatment. . . . . . . . . . . . . . . . . . . . . . . . . . . . 25

Analysis 2.1. Comparison 2 Early treatment at the end of Phase I: headgear versus control, Outcome 1 Final overjet. 25

Analysis 2.2. Comparison 2 Early treatment at the end of Phase I: headgear versus control, Outcome 2 Final ANB. . 26

Analysis 2.3. Comparison 2 Early treatment at the end of Phase I: headgear versus control, Outcome 3 Incidence of incisal trauma during Phase I treatment. . . . . . . . . . . . . . . . . . . . . . . . . . . . 26

Analysis 3.1. Comparison 3 Early treatment at the end of Phase I: headgear versus functional, Outcome 1 Final overjet. 27

Analysis 3.2. Comparison 3 Early treatment at the end of Phase I: headgear versus functional, Outcome 2 Final ANB. 27

Analysis 3.3. Comparison 3 Early treatment at the end of Phase I: headgear versus functional, Outcome 3 ANB change. 28

Analysis 3.4. Comparison 3 Early treatment at the end of Phase I: headgear versus functional, Outcome 4 Incidence of incisal trauma during Phase I treatment. . . . . . . . . . . . . . . . . . . . . . . . . . 28

Analysis 4.1. Comparison 4 Early treatment at the end of Phase II: functional versus control, Outcome 1 Final overjet. 29

Analysis 4.2. Comparison 4 Early treatment at the end of Phase II: functional versus control, Outcome 2 Final ANB. 29

Analysis 4.3. Comparison 4 Early treatment at the end of Phase II: functional versus control, Outcome 3 PAR score. 30

Analysis 4.4. Comparison 4 Early treatment at the end of Phase II: functional versus control, Outcome 4 New incisal trauma during Phase II treatment. . . . . . . . . . . . . . . . . . . . . . . . . . . . . . . . . . . .

Analysis 5.1. Comparison 5 Early treatment at the end of Phase II: headgear versus control, Outcome 1 Final overjet. 31

Analysis 5.2. Comparison 5 Early treatment at the end of Phase II: headgear versus control, Outcome 2 Final ANB. . 31

Analysis 5.3. Comparison 5 Early treatment at the end of Phase II: headgear versus control, Outcome 3 PAR score. . 32

Analysis 5.4. Comparison 5 Early treatment at the end of Phase II: headgear versus control, Outcome 4 New incisal trauma during Phase II treatment. . . . . . . . . . . . . . . . . . . . . . . . . . . . . . . . . 32

Analysis 6.1. Comparison 6 Early treatment at the end of Phase II: headgear versus functional, Outcome 1 Final overjet. 33

Analysis 6.2. Comparison 6 Early treatment at the end of Phase II: headgear versus functional, Outcome 2 Final ANB. 33

Analysis 6.3. Comparison 6 Early treatment at the end of Phase II: headgear versus functional, Outcome 3 PAR score. 34

Analysis 6.4. Comparison 6 Early treatment at the end of Phase II: headgear versus functional, Outcome 4 New incisal trauma during Phase II treatment. . . . . . . . . . . . . . . . . . . . . . . . . . . . 34

Analysis 7.1. Comparison 7 Adolescent treatment: functional versus control, Outcome 1 Final overjet. . . . . . 35

Analysis 7.2. Comparison 7 Adolescent treatment: functional versus control, Outcome 2 Final ANB. . . . . . . . $\quad 35$

Analysis 8.1. Comparison 8 Adolescent treatment: Twin Block versus other functional appliances, Outcome 1 Final ANB. 36

Analysis 8.2. Comparison 8 Adolescent treatment: Twin Block versus other functional appliances, Outcome 2 Final overjet. . . . . . . . . . . . . . . . . . . . . . . . . . 36

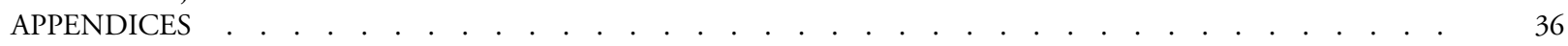

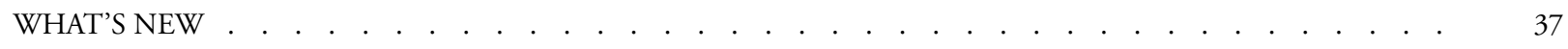

Orthodontic treatment for prominent upper front teeth in children (Review)

Copyright @ 2009 The Cochrane Collaboration. Published by John Wiley \& Sons, Ltd. 
HISTORY . . . . . . . . . . . . . . . . . . . . . . . . . . . . . . . . . . . . . . . 37

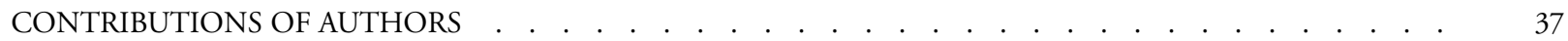

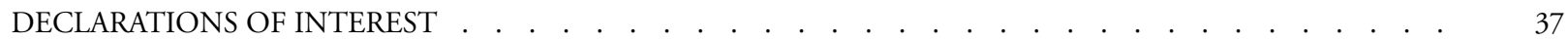

SOURCES OF SUPPORT . . . . . . . . . . . . . . . . . . . . . . . . . . . . . . . . . . . . 38

INDEX TERMS . . . . . . . . . . . . . . . . . . . . . . . . . . . . . . . . . . . . 38 


\title{
[Intervention Review]
}

\section{Orthodontic treatment for prominent upper front teeth in children}

\author{
Jayne E Harrison ${ }^{1}$, Kevin D O’Brien ${ }^{2}$, Helen V Worthington ${ }^{3}$ \\ ${ }^{1}$ Orthodontic Department, Liverpool University Dental Hospital, Liverpool, UK. ${ }^{2}$ Orthodontics, School of Dentistry, The University \\ of Manchester, Manchester, UK. ${ }^{3}$ Cochrane Oral Health Group, MANDEC, School of Dentistry, The University of Manchester, \\ Manchester, UK \\ Contact address: Jayne E Harrison, Orthodontic Department, Liverpool University Dental Hospital, Pembroke Place, Liverpool, \\ Merseyside, L3 5PS, UK. Jayne.Harrison@rlbuht.nhs.uk. jeharrison@hotmail.co.uk. (Editorial group: Cochrane Oral Health Group.)
}

Cochrane Database of Systematic Reviews, Issue 4, 2009 (Status in this issue: Unchanged)

Copyright (C) 2009 The Cochrane Collaboration. Published by John Wiley \& Sons, Ltd.

DOI: $10.1002 / 14651858 . C D 003452$.pub2

This version first published online: 18 July 2007 in Issue 3, 2007.

Last assessed as up-to-date: 14 May 2007. (Help document - Dates and Statuses explained)

This record should be cited as: Harrison JE, O'Brien KD, Worthington HV. Orthodontic treatment for prominent upper front teeth in children. Cochrane Database of Systematic Reviews 2007, Issue 3. Art. No.: CD003452. DOI: 10.1002/14651858.CD003452.pub2.

\begin{abstract}
A B S T R A C T
Background

Prominent upper front teeth are an important and potentially harmful type of orthodontic problem. This condition develops when the child's permanent teeth erupt and children are often referred to an orthodontist for treatment with dental braces to reduce the prominence of the teeth. If a child is referred at a young age, the orthodontist is faced with the dilemma of whether to treat the patient early or to wait until the child is older and provide treatment in early adolescence. When treatment is provided during adolescence the orthodontist may provide treatment with various orthodontic braces, but there is currently little evidence of the relative effectiveness of the different braces that can be used.
\end{abstract}

\section{Objectives}

To assess the effectiveness of orthodontic treatment for prominent upper front teeth, when this treatment is provided when the child is 7 to 9 years old or when they are in early adolescence or with different dental braces or both.

\section{Search strategy}

The Cochrane Oral Health Group's Trials Register, CENTRAL, MEDLINE and EMBASE were searched. The handsearching of the key international orthodontic journals was updated to December 2006. There were no restrictions in respect to language or status of publication.

Date of most recent searches: February 2007.

\section{Selection criteria}

Trials were selected if they met the following criteria:

design - randomised and controlled clinical trials;

participants - children or adolescents (age $\leq 16$ years) or both receiving orthodontic treatment to correct prominent upper front teeth; interventions - active: any orthodontic brace or head-brace, control: no or delayed treatment or another active intervention;

primary outcomes - prominence of the upper front teeth, relationship between upper and lower jaws; 
secondary outcomes: self esteem, any injury to the upper front teeth, jaw joint problems, patient satisfaction, number of attendances required to complete treatment.

\section{Data collection and analysis}

Information regarding methods, participants, interventions, outcome measures and results were extracted independently and in duplicate by two review authors.

The Cochrane Oral Health Group's statistical guidelines were followed and mean differences were calculated using random-effects models. Potential sources of heterogeneity were examined.

\section{Main results}

The search strategy identified 185 titles and abstracts. From this we obtained 105 full reports for the review. Eight trials, based on data from 592 patients who presented with Class II Division 1 malocclusion, were included in the review.

Early treatment comparisons: Three trials, involving 432 participants, compared early treatment with a functional appliance with no treatment. There was a significant difference in final overjet of the treatment group compared with the control group of $-4.04 \mathrm{~mm}$ (95\% CI -7.47 to $\left.-0.6, \mathrm{Chi}^{2} 117.02,2 \mathrm{df}, \mathrm{P}<0.00001, \mathrm{I}^{2}=98.3 \%\right)$. There was a significant difference in ANB $(-1.35 \mathrm{~mm} ; 95 \% \mathrm{CI}-$ 2.57 to $\left.-0.14, \mathrm{Chi}^{2} 9.17,2 \mathrm{df}, \mathrm{P}=0.01, \mathrm{I}^{2}=78.2 \%\right)$ and change in $\mathrm{ANB}\left(-0.55 ; 95 \% \mathrm{CI}-0.92\right.$ to $-0.18, \mathrm{Chi}^{2} 5.71,1 \mathrm{df}, \mathrm{P}=0.06, \mathrm{I}^{2}$ $=65.0 \%)$ between the treatment and control groups.

The comparison of the effect of treatment with headgear versus untreated control revealed that there was a small but significant effect of headgear treatment on overjet of -1.07 (95\% CI -1.63 to -0.51 , $\left.^{-2} \mathrm{i}^{2} 0.05,1 \mathrm{df}, \mathrm{P}=0.82, \mathrm{I}^{2}=0 \%\right)$. Similarly, headgear resulted in a significant reduction in final ANB of $-0.72\left(95 \% \mathrm{CI}-1.18\right.$ to $\left.-0.27, \mathrm{Chi}^{2} 0.34,1 \mathrm{df}, \mathrm{P}=0.56, \mathrm{I}^{2}=0 \%\right)$.

No significant differences, with respect to final overjet, ANB, or ANB change, were found between the effects of early treatment with headgear and the functional appliances.

Adolescent treatment (Phase II): At the end of all treatment we found that there were no significant differences in overjet, final ANB or PAR score between the children who had a course of early treatment, with headgear or a functional appliance, and those who had not received early treatment. Similarly, there were no significant differences in overjet, final ANB or PAR score between children who had received a course of early treatment with headgear or a functional appliance.

One trial found a significant reduction in overjet $(-5.22 \mathrm{~mm}$; 95\% CI -6.51 to -3.93$)$ and ANB (-2.27 degrees; $95 \%$ CI -3.22 to -1.31 , $\left.\mathrm{Chi}^{2} 1.9,1 \mathrm{df}, \mathrm{P}=0.17, \mathrm{I}^{2}=47.3 \%\right)$ for adolescents receiving one-phase treatment with a functional appliance versus an untreated control.

A statistically significant reduction of ANB (-0.68 degrees; $95 \%$ CI -1.32 to -0.04 , $\left.\mathrm{Chi}^{2} 0.56,1 \mathrm{df}, \mathrm{P}=0.46, \mathrm{I}^{2}=0 \%\right)$ with the Twin Block appliance when compared to other functional appliances. However, there was no significant effect of the type of appliance on the final overjet.

\section{Authors' conclusions}

The evidence suggests that providing early orthodontic treatment for children with prominent upper front teeth is no more effective than providing one course of orthodontic treatment when the child is in early adolescence.

\section{PLAIN LANGUAGE SUMMARY}

\section{Orthodontic treatment for prominent upper front teeth in children}

Prominent upper front teeth are an important and potentially harmful type of orthodontic problem. This condition develops when the child's permanent teeth erupt and children are often referred to an orthodontist for treatment with dental braces to reduce the prominence of the teeth. If a child is referred at a young age, the orthodontist is faced with the dilemma of whether to treat the patient early or to wait until the child is older and provide treatment in early adolescence.

The evidence suggests that providing orthodontic treatment, for children with prominent upper front teeth, in two stages does not have any advantages over providing treatment in one stage, when the children are in early adolescence. 


\section{B A C K G R O U N D}

Orthodontics is the branch of dentistry concerned with the growth of the jaws and face, the development of the teeth and the way the teeth and jaws bite together. It also involves treatment of the teeth and jaws when they are irregular or bite in an abnormal way or both. There are many reasons why the teeth may not bite together correctly. These include the position of the teeth, jaws, lips, tongue, and/or cheeks or may be due to a habit or the way people breath. The need for orthodontic treatment can be decided by looking at the effect any particular tooth position has on the life expectancy of the teeth or the effect that the appearance of the teeth has on how people feel about themselves or both (Shaw 1991).

Prominent upper front teeth (Class II malocclusion) may be due to any combination of the jaw, tooth and/or lip position. The upper jaw (maxilla) can be too far forward or, more usually, the lower jaw (mandible) is too far back. The upper front teeth (incisors) may stick out if the lower lip catches behind them or due to a habit e.g. thumb sucking. This gives the patient an appearance that may be a target for teasing (Shaw 1980). When front teeth stick out (more than $3 \mathrm{~mm}$ ) they are twice as likely to be injured (Nguyen 1999). Prominent upper front teeth (Class II malocclusion) is one of the most common problems seen by orthodontists and affects about a quarter of 12 year old children in the UK (Holmes 1992). However, there are racial differences. Prominent upper front teeth (Class II malocclusion) are most common in whites of Northern European origin and least common in black and oriental races and some Scandinavian populations (El-Mangoury 1990; Proffit 1993; Silva 2001).

Several dental brace (orthodontic) treatments have been suggested to correct prominent upper front teeth (Class II malocclusions). Some treatments aim to move the upper front teeth backwards whilst others aim to modify the growth of the upper or lower jaw or both to reduce the prominence of the upper front teeth. Treatment can involve the use of one or more types of orthodontic brace. Some braces apply a force directly to the teeth and can either be removed from the mouth or fixed to the teeth, with special glue, during treatment. Other types of brace are attached, via the teeth, to devices (headgear) that allow a force to be applied to the teeth and jaws from the back of the head. Treatment is usually carried out either early (early treatment), when the patients have a mixture of their baby and adult teeth present (around 7 to 11 years of age) or later (adolescent treatment) when all the adult teeth have come into the mouth (around 12 to 16 years of age). In severe cases and some adult patients, orthodontic treatment may need to be combined with jaw surgery to correct the position of one or both jaws.

\section{O B J E C T I VES}

To assess the effectiveness of orthodontic treatment for prominent upper front teeth, when this treatment is provided when the child is 7 to 9 years old or when they are in early adolescence or with different dental braces or both.

To test the null hypotheses that there are no differences in outcomes between:

- the age at which orthodontic treatment for prominent upper front teeth is carried out;

- different orthodontic interventions for correcting prominent upper front teeth against the alternative that there are.

\section{METHODS}

\section{Criteria for considering studies for this review}

\section{Types of studies}

All randomised and controlled clinical trials of orthodontic treatments to correct prominent upper front teeth.

\section{Types of participants}

Children or adolescents (age 16 years or less) or both receiving orthodontic treatment to correct prominent upper front teeth. Trials including patients with a cleft lip or palate or both, or other craniofacial deformity/syndrome were excluded as were trials that had recruited less than $80 \%$ children or adolescents or patients who had previously received surgical treatment for their Class II malocclusion.

\section{Types of interventions}

- Active interventions: Orthodontic braces (removable, fixed, functional) or head-braces.

- Control: No treatment, delayed treatment or another active intervention.

\section{Types of outcome measures}

- Primary: Prominence of the upper front teeth (overjet measured in mm or by any index of malocclusion).

- Secondary: Relationship between upper and lower jaws, self esteem, patient satisfaction, any injury to the upper front teeth, jaw joint problems, number of attendances required to complete treatment.

- Harms: Health of the gums, damage to the teeth e.g. tooth decay.

We recorded these outcomes at all ages and the most common endpoints that were reported. If we identified harms these were recorded and reported in descriptive terms. 


\section{Search methods for identification of studies}

We developed detailed search strategies for the identification of studies for each database searched. These were initially based on the search strategy developed for MEDLINE and then revised appropriately for each database. Our subject search strategy used a combination of controlled vocabulary and free text terms based on the search strategy for MEDLINE, in conjunction with phases 1 and 2 of the Cochrane Sensitive Search Strategy for Randomised Controlled Trials (RCTs) as published in the Cochrane Handbook for Systematic Reviews of Interventions 4.2.6, Appendix 5b. See Appendix 1.

\section{Databases searched}

We searched the following databases:

Cochrane Oral Health Group's Trials Register (to February 2007) Cochrane Central Register of Controlled Trials (CENTRAL) (The Cochrane Library 2007, Issue 1)

MEDLINE (1966 to February 2007)

EMBASE (1980 to February 2007).

\section{Handsearching}

We obtained articles that were identified as part of the Cochrane Oral Health Group's handsearching programme, from the following journals: American Journal of Orthodontics and Dentofacial Orthopedics, The Angle Orthodontist, European Journal of Orthodontics, and Journal of Orthodontics. In addition, we handsearched the following journals from their inception to December 2006: Seminars in Orthodontics (from 1995 to December 2006), Clinical Orthodontics and Research (from 1998 to December 2006) and Australian Journal of Orthodontics (from 1956 to December 2006).

The bibliographies of the clinical trials that we identified were checked for references to trials published outside the handsearched journals, including personal references.

\section{Language}

Databases were searched to include all languages and we would have attempted translated any non-English language papers that we found.

\section{Unpublished studies}

The first named authors of all trial reports were contacted in an attempt to identify unpublished studies and to obtain any further information about the trials.

\section{Data collection and analysis}

\section{Study selection}

Two review authors (Jayne Harrison (JH) and Kevin O'Brien (KOB)) independently and in duplicate assessed the eligibility of all reports that we identified by the search strategy as being potentially relevant to the review. We were not blind to author(s), institution or site of publication. Agreement was assessed using the kappa statistic (Landis 1977). Disagreements were resolved by discussion or following clarification from authors.

\section{Data extraction}

Two review authors ( $\mathrm{JH}$ and $\mathrm{KOB}$ ) then independently and in duplicate extracted data using a specially designed data extraction form. We recorded the year of publication, interventions assessed, outcomes, sample size and age of subjects.

The primary outcome was prominence of the upper front teeth and the secondary outcomes were relationship of upper and lower jaws, self esteem, patient satisfaction, jaw joint problems, number of attendances and any injury to the upper front teeth. Harms e.g. health of the gums, damage to the teeth.

We grouped the outcome data into those measured at the end of early treatment and following adolescent treatment.

\section{Quality assessment}

The quality assessment was undertaken independently and in duplicate by two review authors ( $\mathrm{JH}$ and $\mathrm{KOB}$ ) as part of the data extraction process. The methodological quality of UK (11-14); UK (Mixed) were assessed independently by Helen Worthington (HW).

Four main quality criteria were examined:

(1) Allocation concealment, recorded as:

(A) Adequate

(B) Unclear

(C) Inadequate as described in the Cochrane Handbook for Systematic Reviews on Interventions 4.2.6.

(2) Blind outcome assessment

(3) Completeness of follow up

(4) Intention-to-treat analysis.

\section{Data analysis}

For dichotomous outcomes, the estimates of effect of an intervention were expressed as odds ratios together with $95 \%$ confidence intervals (CIs). For continuous outcomes, mean differences and standard deviations were used to summarise the data for each group.

Only if there were studies of similar comparisons reporting the same outcome measures was meta-analysis to be attempted. Odds ratios were to be combined for dichotomous data, and mean differences for continuous data, using random-effects models.

The significance of any discrepancies in the estimates of the treatment effects from the different trials was to be assessed by means of Cochran's test for heterogeneity and the $\mathrm{I}^{2}$ statistic, which describes the percentage total variation across studies that is due to heterogeneity rather than chance. Clinical heterogeneity was to be assessed by examining the types of participants and interventions for all outcomes in each study. It was planned to undertake sensitivity analyses to examine the effect of the study quality assessment on the overall estimates of effect. In addition, the effect of including unpublished literature on the review's findings was also to be examined, but there were insufficient trials to undertake this. 


\section{R E S U L T S}

\section{Description of studies}

See: Characteristics of included studies; Characteristics of excluded studies.

\section{Results of the search}

Electronic searches identified 185 titles and abstracts. From this we obtained 105 full reports for the review. Eight trials, involving data from 592 participants, were included in the review. This included contemporary unpublished data from the Florida; UK (11-14) studies.

\section{Included studies}

See Characteristics of included studies table.

\section{Characteristics of the trial settings and investigators}

Of the included trials, three were conducted in the United Kingdom (London; UK (11-14); UK (Mixed)), two were carried out in North America (Florida; North Carolina), one was conducted in China (Mao 1997), one in New Zealand (New Zealand) and one in Turkey (Cura 1997). All trials had a parallel group design. Two were multicentre studies (UK (11-14); UK (Mixed)). Five of the trials had more than one publication. Four of the trials received external funding. The percentage of patients lost to follow up varied from $0 \%$ to $26 \%$. The providers and assessors were dental staff.

\section{Characteristics of the participants}

Four trials provided treatment for children aged between 8 and 11 years old (Florida; New Zealand; North Carolina; UK (Mixed)). Four provided treatment for children who were 10 to 15 years old (Cura 1997; London; Mao 1997; UK (11-14)). Two of the trials had an active recruitment strategy that involved screening school children and providing incentives, such as reduced fees, for participation (Florida; North Carolina).

\section{Characteristics of the interventions}

All of the trials provided a clear description of the treatment protocols. Three trials included an untreated control group (Cura 1997;
Mao 1997; New Zealand), three used a delayed treatment control group (Florida; North Carolina; UK (Mixed)) and two compared two or more types of orthodontic appliances (London; UK (1114)). Three evaluated the effects of early treatment and followed the children through to the completion of all treatment in adolescence (Florida; New Zealand; North Carolina). One had a similar design, but is not yet complete (UK (Mixed)).

The interventions for the treatment of Class II malocclusion could be classified as:

- Early treatment followed by adolescent treatment ( Florida; New Zealand; North Carolina; UK (Mixed))

- Adolescent treatment only (Cura 1997; London; Mao 1997).

\section{Excluded studies}

See Characteristics of excluded studies table. Of the 65 studies that were excluded:

- 21 were not a controlled or a randomised clinical trial (CCT/RCT);

- 25 had unclear methods

- 6 were review articles that yield no extra references;

- 5 did not involve treatment of patients with a Class II malocclusion;

- 6 reported outcomes that were not of interest; and

- 2 were excluded for other reasons.

\section{Risk of bias in included studies}

Allocation concealment was adequate for four of the trials but it was unclear for the remaining (Additional Table 1). The outcome assessor was blinded for three trials, but this was not clear for the others. Withdrawals were adequately reported in all of the eight trials. The kappa scores between the two raters were 1.0 for allocation concealment, 1.0 for blinding of outcome assessment and 0.9 for clear information on withdrawals.

Table 1. Quality assessment of included trials

\begin{tabular}{lllll}
\hline Trial & Allocation concealment & Blinded outcome & Clear withdrawals & Risk of bias \\
\hline Cura 1997 & Unclear & Unclear & Yes & Moderate \\
\hline Florida & Yes & Yes & Yes & Low \\
\hline London & Unclear & No & Yes & Moderate
\end{tabular}


Table 1. Quality assessment of included trials (Continued)

\begin{tabular}{lllll}
\hline Mao 1997 & Unclear & Unclear & Yes & Moderate \\
\hline New Zealand & Unclear & Yes & Yes & Moderate \\
\hline North Carolina & Yes & Yes & Yes & Low \\
\hline UK (11-14) & Yes & Yes & Yes & Low \\
\hline UK (Mixed) & Yes & Yes & Yes & Low \\
\hline
\end{tabular}

Four trials were assessed as low risk of bias (Florida; North Carolina; UK (11-14); UK (Mixed)) and four were thought to have moderate risk bias (Cura 1997; London; Mao 1997; New Zealand). The methodological quality of UK (Mixed) and UK (11-14) were assessed independently by Helen Worthington.

\section{Effects of interventions}

Electronic searches identified 185 titles and abstracts. From these 105 full papers were retrieved for further assessment. Of these, 71 references to 65 trials were excluded. Thirty-four references to eight trials met the defined criteria for trial design, participants, interventions and outcomes.

For the eight trials included in the review the results are based on data from 592 patients who presented with Class II Division 1 malocclusion. The number of participants in each treatment/control group ranged from 15 to 95 .

We divided the trials into two main groups:

(i) those that reported the effects of early treatment (Phase I treatment) at either the end of Phase I or follow up to the end of Phase II and

(ii) those that reported the effects of treatment that was provided as one phase in adolescence.

\section{Early treatment comparisons}

\section{Comparisons with early treatment appliance versus untreated control (Comparison I; Outcomes I.I-I.4)}

Three trials, involving 432 participants, compared early treatment, using a functional appliance, with no treatment. The meta-analysis showed that there was a statistically significant difference in final overjet of the treatment group compared with the control group ( $-4.04 \mathrm{~mm}$; $95 \%$ confidence interval (CI) -7.47 to -0.6 , $\mathrm{Chi}^{2}$ 117.02, 2 degrees of freedom (df), $\mathrm{P}<0.00001, \mathrm{I}^{2}=98.3 \%$ ).

When we evaluated the effect of treatment on the final ANB, we found that there was a significant difference between the treatment and control groups $\left(-1.35 \mathrm{~mm}\right.$; $95 \% \mathrm{CI}-2.57$ to $-0.14, \mathrm{Chi}^{2} 9.17$, $\left.2 \mathrm{df}, \mathrm{P}<0.01, \mathrm{I}^{2}=78.2 \%\right)$. Similarly, there was a statistically significant difference ( -0.55 degrees; $95 \%$ CI -0.92 to -0.18 , Chi $^{2}$ $\left.5.71,2 \mathrm{df}, \mathrm{P}=0.06, \mathrm{I}^{2}=65.0 \%\right)$ in the change in ANB between the treatment and control groups.

Early treatment also had a statistically significant effect on the PAR score with the early treatment groups having a PAR score that was 12.63 PAR points (95\% CI -22.8 to -2.99 , $\mathrm{Chi}^{2} 56.53,2 \mathrm{df}, \mathrm{P}<$ $\left.0.00001, \mathrm{I}^{2}=96.5 \%\right)$ lower than the control groups.

\section{Comparisons of early treatment with headgear versus} untreated control (Comparison 2; Outcomes 2.1-2.2)

The comparison of the effect of treatment with headgear, compared with untreated control, revealed that there was a small, but statistically significant, effect of headgear treatment on the overjet (-1.07 mm; 95\% CI -1.63 to -0.51, Chi ${ }^{2} 0.05,1 \mathrm{df}, \mathrm{P}=<0.82, \mathrm{I}^{2}$ $=0 \%)$. Similarly, headgear resulted in a significant reduction of 0.72 degrees $\left(95 \% \mathrm{CI}-1.18\right.$ to $-0.27, \mathrm{Chi}^{2}=0.34,1 \mathrm{df}, \mathrm{P}=0.56$, $\left.\mathrm{I}^{2}=0 \%\right)$ in final ANB.

Comparisons of early treatment with headgear versus functional appliance (Comparison 3; Outcomes 3.1-3.3)

When we compared the effects of early treatment between headgear and the functional appliances we found no statistically significant differences with respect to final overjet, ANB, or ANB change.

\section{Effects of early treatment at the end of adolescent treatment (two-phase treatment)}

\section{Comparisons with early treatment versus untreated control} (Comparison 4; Outcomes 4.1-4.3)

When we evaluated the effects of a course of early treatment, with headgear or a functional appliance, at the end of all orthodontic treatment, we found that there were no statistically significant differences in the overjet, final ANB or PAR score compared with an untreated control.

Comparisons of early treatment with headgear versus control (Comparison 5; Outcomes 5.1-5.3) 
Similarly, there were no statistically significant effects of an early course of headgear treatment at the end of Phase II treatment with respect to overjet, final ANB or PAR score compared with an untreated control.

\section{Comparisons of early treatment with headgear versus functional appliance (Comparison 6; Outcomes 6.1-6.3)}

An evaluation of the effect of early treatment between headgear and functional appliance revealed that were no significant differences in overjet, final ANB or PAR score.

\section{One-phase adolescent treatment comparisons}

Comparisons of one-phase adolescent treatment functional appliance versus untreated control (Comparison 7; Outcome 7.1)

We only found one trial addressing this outcome (Cura 1997). There was a statistically significant reduction in overjet of -5.22 $\mathrm{mm}(95 \% \mathrm{CI}-6.51$ to $-3.93, \mathrm{P}<0.0001)$ for the treatment group compared with an untreated control.

Comparisons of one-phase adolescent treatment functional appliance versus untreated control (Comparison 7; Outcome 7.2)

The evaluation of the effect of functional appliance on ANB revealed a statistically significant reduction in ANB of -2.27 degrees (95\% CI -3.22 to $-1.31, \mathrm{Chi}^{2} 1.9,1 \mathrm{df}, \mathrm{P}=0.17, \mathrm{I}^{2}=47.3 \%$ ) compared with an untreated control.

\section{Comparisons of one-phase adolescent treatment with the} Twin Block functional appliance versus other functional appliances (Comparison 8; Outcomes 8.1-8.2)

This comparison revealed that there was statistically significant reduction on ANB with the Twin Block when compared to other functional appliances. This was only -0.68 degrees $(95 \% \mathrm{CI}-1.32$ to $\left.-0.04, \mathrm{Chi}^{2} 0.56,1 \mathrm{df}, \mathrm{P}=0.46, \mathrm{I}^{2}=0 \%\right)$. However, there was no statistically significant effect of the type of appliance on final overjet.

\section{DISCUSSION}

\section{Two-phase versus one-phase treatment}

We have found evidence that when orthodontic treatment is provided for children with prominent upper front teeth, when they are aged 7 to 9 years old (early treatment), this results in clinically and statistically significant reduction in incisor prominence.
This effect occurs if the child received treatment with a functional appliance or headgear. This treatment also resulted in some changes in the relationship of the upper and lower jaws. However, while these changes or differences were statistically significant they were unlikely to be clinically significant. As these studies were of high/moderate quality, carried out in several different countries, using different functional appliances on children who were representative of the population, we can conclude that the resuls of this review are generalisable.

When we considered the final outcome of treatment at the end of a second phase of treatment when the child was in early adolescence, we found that the treatment was effective, in that incisor prominence had been reduced. Nevertheless, there were no differences in treatment outcome between the groups of children who had received one or two phases of treatment. As a result, it appears that two-phase treatment does not have any advantages over onephase treatment.

\section{Treatment provided in one phase in early adolescence}

We found two studies that measured the effect of treatment with functional appliance versus an untreated control. The analysis revealed that the treatment resulted in a reduction of overjet and a change in skeletal pattern, but again this change was so small that it may not be of clinical significance.

We also found that several investigators had compared the effect of the Twin Block functional appliance against other similar appliances, for example, the Bionator and Herbst appliances. We found that while there was a statistically significant difference in ANB however, this was so small that it was unlikely to be of clinical significance. We did not find any other significant differences. One important finding from this review was that while we identified eight randomised controlled trials, they had been published in 34 different papers. Furthermore, several of the investigators had not only reported outcomes at the end of early treatment but they had produced several papers that were confined to analysis of subsets of subjects, to form interim reports or 'updates'. While they may have had good reasons to follow this publication strategy, in terms of having to compete for the renewal of grant funding, this did result in difficulty interpreting the results of these studies. We approached this problem by identifying the most relevant outcomes and data points and then produced composite data extraction for these studies. We would like to suggest that studies are not reported until they are completed. The registration of trials will come some way to addressing some of these issues, where each trial has a unique identity number which will apear on all publications. The quality of the trials in this review was fair with $50 \%$ being considered at low risk of bias, the remainder at moderate risk. This was mainly due to the lack of blinding of the outcome assessors. Finally, there was great variation in the outcome measures that were adopted by the investigators. This was particularly marked with 
the use of cephalometric analyses and is not surprising when we consider that there are many different types of analysis. We would suggest that when future studies are planned uniformly applied cephalometric analyses are utilised, so that adequate comparisons between trials can be achieved.

\section{A U THORS, CONCLUSIONS}

\section{Implications for practice}

Early orthodontic treatment (Phase I), followed by a later phase of treatment (Phase II) when the child is in early adolescence, does not appear to have any advantages over treatment that is provided in one phase when the child is in early adolescence.

When functional appliance treatment is provided in early adolescence it appears that there are minor beneficial changes in skeletal pattern, however, these are probably not clinically significant. Similarly, the choice of functional appliance when compared to the Twin Block does not result in any advantageous effects.

\section{Implications for research}

Consideration needs to be given to forming a consensus on the type of measures that are used in orthodontic trials, this is particularly relevant for cephalometric measurement and analysis. In addition, studies should be carried out at the same time points and reported according to the Consolidated Standards of Reporting Trials (CONSORT) guidelines.

\section{ACKNOWLEDGEMENTS}

Thanks to Sylvia Bickley (Cochrane Oral Health Group) for her help in conducting the searches, and to Luisa Fernandez Mauleffinch (Cochrane Oral Health Group) for editorial management of the review. Thanks to Bill Shaw for his initial advice, Bill Proffit, Kitty Tulloch (University of North Carolina), Tim Wheeler, Sue McGorry (University of Florida), David Morris; Danny Op Heij and Urban Hagg for providing additional data for this review; John Scholey for undertaking some of the handsearching and Sue Pender for retrieving, copying and collating the full papers. We would also like to thank all those who have provided comments and editorial input into this review.

\section{REFERENCE S}

\section{References to studies included in this review}

Cura 1997 \{published data only\}

Cura N, Sarac M. The effect of treatment with the Bass appliance on skeletal Class II malocclusions: a cephalometric investigation. European Journal of Orthodontics 1997;19(6):691-702.

Florida \{published and unpublished data\}

Johnson PD, Cohen DA, Aiosa L, McGorray S, Wheeler T. Attitudes and compliance of pre-adolescent children during early treatment of Class II malocclusion. Clinical Orthodontics and Research 1998;1(1): $20-8$.

Keeling SD, Garvan CW, King GJ, Wheeler TT, McGorray S. Temporomandibular disorders after early Class II treatment with bionators and headgears: results from a randomized controlled trial. Seminars in Orthodontics 1995;1(3):149-64.

* Keeling SD, Wheeler TT, King GJ, Garvan CW, Cohen DA, Cabassa S, et al.Anteroposterior skeletal and dental changes after early Class II treatment with bionators and headgear. American Journal of Orthodontics and Dentofacial Orthopedics 1998;113(1):40-50.

King GJ, McGorray SP, Wheeler TT, Dolce C, Taylor M. Comparison of peer assessment ratings (PAR) from 1-phase and 2-phase treatment protocols for Class II malocclusions. American Journal of Orthodontics and Dentofacial Orthopedics 2003;123(5):489-96.

King GJ, Wheeler TT, McGorray SP. Randomised prospective clinical trial evaluating early treatment of Class II malocclusions. European Journal of Orthodontics 1999;21(4):445.

Wheeler TT, McGorray SP, Dolce C, Taylor MG, King GJ. Effective- ness of early treatment of Class II malocclusion. American Journal of Orthodontics and Dentofacial Orthopedics 2002;121(1):9-17.

Wortham JR, McGorray S, Taylor M, Dolce C, King DJ, Wheeler TT. Arch dimension changes following phase I and phase II orthodontic class II treatment. Journal of Dental Research 2001;80(Spec Issue (AADR Abstracts)):177 (Abs No 1131).

London \{published data only\}

* Illing HM, Morris DO, Lee RT. A prospective evaluation of Bass, Bionator and Twin Block appliances. Part I--The hard tissues. European Journal of Orthodontics 1998;20(5):501-16.

McDonagh S, Moss JP, Goodwin P, Lee RT. A prospective optical surface scanning and cephalometric assessment of the effect of functional appliances on the soft tissues. European Journal of Orthodontics 2001;23(2):115-26.

Morris DO, Illing HM, Lee RT. A prospective evaluation of Bass, Bionator and Twin Block appliances. Part II--The soft tissues. European Journal of Orthodontics 1998;20(6):663-84.

Mao 1997 \{published data only\}

Mao J, Zhao H. The correction of Class II, division 1 malocclusion with bionator headgear combination appliance. Journal of Tongji Medical University 1997;17(4):254-6.

\section{New Zealand \{published data only\}}

Courtney M, Harkness M, Herbison P. Maxillary and cranial base changes during treatment with functional appliances. American Journal of Orthodontics and Dentofacial Orthopedics 1996;109(6):61624.

Nelson C, Harkness M, Herbison P. Mandibular changes during 
functional appliance treatment. American Journal of Orthodontics and Dentofacial Orthopedics 1993;104(2):153-61.

O'Neill K, Harkness M, Knight R. Ratings of profile attractiveness after functional appliance treatment. American Journal of Orthodontics and Dentofacial Orthopedics 2000;118(4):371-6.

Webster T, Harkness M, Herbison P. Associations between changes in selected facial dimensions and the outcome of orthodontic treatment. American Journal of Orthodontics and Dentofacial Orthopedics 1996; 110(1):46-53

* Wijayaratne D, Harkness M, Herbison P. Functional appliance treatment assessed using the PAR index. Australian Orthodontic Journal 2000;16(3):118-26.

\section{North Carolina \{published data only\}}

Almeida MA, Phillips C, Kula K, Tulloch C. Stability of the palatal rugae as landmarks for analysis of dental casts. The Angle Orthodontist 1995;65(1):43-8.

Brin I, Tulloch JF, Koroluk L, Philips C. External apical root resorption in Class II malocclusion: a retrospective review of 1- versus 2phase treatment. American Journal of Orthodontics and Dentofacial Orthopedics 2003;124(2):151-6.

Dann C 4th, Phillips C, Broder HL, Tulloch JF. Self-concept, Class II malocclusion, and early treatment. The Angle Orthodontist 1995; 65(6):411-6.

Ehmer U, Tulloch CJ, Proffit WR, Phillips C. An international comparison of early treatment of angle Class-II/1 cases. Skeletal effects of the first phase of a prospective clinical trial. Journal of Orofacial Orthopedics 1999;60(6):392-408.

Koroluk LD, Tulloch JF, Phillips C. Incisor trauma and early treatment for Class II Division 1 malocclusion. American Journal of Orthodontics and Dentofacial Orthopedics 2003;123(2):117-26.

Proffit WR, Tulloch JF. Preadolescent Class II problems: treat now or wait?. American Journal of Orthodontics and Dentofacial Orthopedics 2002;121(6):560-2.

Tulloch JF. Early versus late treatment for Class II maolcclusions. European Journal of Orthodontics 1999;21(4):453.

Tulloch JF, Phillips C, Koch G, Proffit WR. The effect of early intervention on skeletal pattern in Class II malocclusion: a randomized clinical trial. American Journal of Orthodontics and Dentofacial Orthopedics 1997;111(4):391-400.

Tulloch JF, Phillips C, Proffit WR. Benefit of early Class II treatment: progress report of a two-phase randomized clinical trial. American Journal of Orthodontics and Dentofacial Orthopedics 1998;113(1):6272.

Tulloch JF, Proffit WR, Phillips C. Influences on the outcome of early treatment for Class II malocclusion. American Journal of Orthodontics and Dentofacial Orthopedics 1997;111(5):533-42.

* Tulloch JF, Proffit WR, Phillips C. Outcomes in a 2-phase randomized clinical trial of early Class II treatment. American Journal of Orthodontics and Dentofacial Orthopedics 2004;125(6):657-67.

Tulloch JF, Rogers L, Phillips C. Early results from a randomized clinical trial of growth modification in Class II malocclusion. Journal of Dental Research 1992;72(Spec Issue (IADR Abstracts)):523.

\section{UK (11-14) \{published and unpublished data\}}

O'Brien K, Wright J, Conboy F, Sanjie Y, Mandall N, Chadwick $S$, et al.Effectiveness of treatment for Class II malocclusion with the Herbst or twin-block appliances: a randomized, controlled trial.
American Journal of Orthodontics and Dentofacial Orthopedics 2003; 124(2):128-37.

\section{UK (Mixed) \{published and unpublished data\}}

O'Brien K, Wright J, Conboy F, Chadwick S, Connolly I, Cook P, et al.Effectiveness of early orthodontic treatment with the Twinblock appliance: a multicenter, randomized, controlled trial. Part 2: Psychosocial effects. American Journal of Orthodontics and Dentofacial Orthopedics 2003;124(5):488-94.

* O'Brien K, Wright J, Conboy F, Sanjie Y, Mandall N, Chadwick $S$, et al.Effectiveness of early orthodontic treatment with the Twinblock appliance: a multicenter, randomized, controlled trial. Part 1: Dental and skeletal effects. American Journal of Orthodontics and Dentofacial Orthopedics 2003;124(3):234-43.

O'Brien $\mathrm{K}$, et al.The effectiveness of two stage treatment for Class II malocclusion. American Journal of Orthodontics and Dentofacial Orthopedics 2006 in press.

\section{References to studies excluded from this review}

\section{Ackerman 2004 \{published data only\}}

Ackerman M. Evidence-based orthodontics for the 21st century. Journal of the American Dental Association 2004;135(2):162-7.

\section{Aelbers 1996 \{published data only\}}

Aelbers CM, Dermaut LR. Orthopedics in orthodontics: Part I, Fiction or reality--a review of the literature. American Journal of Orthodontics and Dentofacial Orthopedics 1996;110(5):513-9.

\section{Aknin 2000 \{published data only\}}

Aknin JJ, Morra L. Comparative study of mandibular growth and rotation in two sample groups treated according to the "Distal Active Concept" or the Edgewise technique. L'Orthodontie Francaise 2000; 71(4):343-61.

\section{Ashmore 2002 \{published data only\}}

Ashmore JL, Kurland BF, King GJ, Wheeler TT, Ghafari J, Ramsay DS. A 3-dimensional analysis of molar movement during headgear treatment. American Journal of Orthodontics and Dentofacial Orthopedics 2002;121(1):18-30.

Banks 2004 \{published data only\} Banks P, Wright J, O’Brien K. Incremental versus maximum bite advancement during twin-block therapy: a randomized controlled clinical trial. American Journal of Orthodontics and Dentofacial Orthopedics 2004;126(5):583-8.

\section{Bishara 1995 \{published data only\}}

Bishara SE, Cummins DM, Jakobsen JR, Zaher AR. Dentofacial and soft tissue changes in Class II, division 1 cases treated with and without extractions. American Journal of Orthodontics and Dentofacial Orthopedics 1995;107(1):28-37.

\section{Boecler 1989 \{published data only\}}

Boecler PR, Riolo ML, Keeling SD, TenHave TR. Skeletal changes associated with extraoral appliance therapy: an evaluation of 200 consecutively treated cases. The Angle Orthodontist 1989;59(4):26370 .

Cevidanes 2003 \{published data only\}

Cevidanes LH, Franco AA, Scanavini MA, Vigorito JW, Enlow DH, Proffit WR. Clinical outcomes of Frankel appliance therapy assessed with a counterpart analysis. American Journal of Orthodontics and Dentofacial Orthopedics 2003;123(4):379-87. 
Chen 2002 \{published data only\}

Chen JY, Will LA, Niederman R. Analysis of efficacy of functional appliances on mandibular growth. American Journal of Orthodontics and Dentofacial Orthopedics 2002;122(5):470-6.

Chintakanon 2000 \{published data only\}

Chintakanon K, Sampson W, Wilkinson T, Townsend G. A prospective study of Twin-block appliance therapy assessed by magnetic resonance imaging. American Journal of Orthodontics and Dentofacial Orthopedics 2000;118(5):494-504.

\section{Collett 2000 \{published data only\}}

Collett AR. Current concepts on functional appliances and mandibular growth stimulation. Australian Dental Journal 2000;45(3):1738 .

Cura 1996 \{published data only\}

Cura N, Sarac M, Ozturk Y, Surmeli N. Orthodontic and orthopedic effects of Activator, Activator-HG combination, and Bass appliances: a comparative study. American Journal of Orthodontics and Dentofacial Orthopedics 1996;110(1):36-45.

Dahan 1989 \{published data only\}

Dahan J, Serhal JB, Englebert A. Cephalometric changes in Class II, Division 1 cases after orthopedic treatment with the bioactivator. American Journal of Orthodontics and Dentofacial Orthopedics 1989; 95(2):127-37.

De Almeida 2002 \{published data only\}

De Almeida MR, Henriques JF, Ursi W. Comparative study of the Frankel (FR-2) and bionator appliances in the treatment of Class II malocclusion. American Journal of Orthodontics and Dentofacial Orthopedics 2002;121(5):458-66.

DeVincenzo 1989 \{published data only\}

DeVincenzo JP, Winn MW. Orthopedic and orthodontic effects resulting from the use of a functional appliance with different amounts of protrusive activation. American Journal of Orthodontics and Dentofacial Orthopedics 1989;96(3):181-90.

Du 2002 \{published data only\}

Du X, Hagg U, Rabie AB. Effects of headgear Herbst and mandibular step-by-step advancement versus conventional Herbst appliance and maximal jumping of the mandible. European Journal of Orthodontics 2002;24(2):167-74.

Erverdi 1995 \{published data only\}

Erverdi N, Ozkan G. A cephalometric investigation of the effects of the Elastic Bite-block in the treatment of Class II division 1 malocclusions. European Journal of Orthodontics 1995;17(5):375-84.

Falck 1989 \{published data only\}

Falck F, Frankel R. Clinical relevance of step-by-step mandibular advancement in the treatment of mandibular retrusion using the Frankel appliance. American Journal of Orthodontics and Dentofacial Orthopedics 1989;96(4):333-41.

Firouz 1992 \{published data only\}

Firouz M, Zernik J, Nanda R. Dental and orthopedic effects of highpull headgear in treatment of Class II, division 1 malocclusion. American Journal of Orthodontics and Dentofacial Orthopedics 1992;102 (3):197-205.

Franco 2002 \{published data only\}

Franco AA, Yamashita HK, Lederman HM, Cevidanes LH, Proffit WR, Vigorito JW. Frankel appliance therapy and the temporo- mandibular disc: a prospective magnetic resonance imaging study. American Journal of Orthodontics and Dentofacial Orthopedics 2002; 121(5):447-57.

\section{Ghafari 1995 \{published data only\}}

Ghafari JG, Shofer FS, Laster LL, Markowitz DL, Silverton S, Katz $\mathrm{SH}$. Monitoring growth during orthodontic treatment. Seminars in Orthodontics 1995;1(3):165-75.

\section{Ghiglione 2000 \{published data only\}}

Ghiglione V, Maspero C, Garagiola U. Skeletal Class II therapy Effects of Bionator and Teuscher appliances. European Journal Orthodontics 2000;22(4):445.

Gianelly 1983 \{published data only\}

Gianelly AA, Brosnan P, Martignoni M, Bernstein L. Mandibular growth, condyle position and Frankel appliance therapy. The Angle Orthodontist 1983;53(2):131-42.

Guner 2003 \{published data only\}

Guner DD, Ozturk Y, Sayman HB. Evaluation of the effects of functional orthopaedic treatment on temporomandibular joints with single-photon emission computerized tomography. European Journal of Orthodontics 2003;25(1):9-12.

Hagg 2002 \{published data only\}

Hagg U, Tse EL, Rabie AB, Robinson W. A comparison of splinted and banded Herbst appliances: treatment changes and complications. Australian Orthodontic Journal 2002;18(2):76-81.

\section{Harvold 1971 \{published data only\}}

Harvold EP, Vargervik K. Morphogenetic response to activator treatment. American Journal of Orthodontics 1971;60(5):478-90.

\section{Hiyama 2002 \{published data only\}}

Hiyama S, Kuribayashi G, Ono T, Ishiwata Y, Kuroda T. Nocturnal masseter and suprahyoid muscle activity induced by wearing a bionator. Angle Orthod 2002;72(1):48-54.

\section{Ingervall 1991 \{published data only\}}

Ingervall, B. Thuer, U. Temporal muscle activity during the first year of Class II, division 1 malocclusion treatment with an activator. American Journal of Orthodontics and Dentofacial Orthopedics 1991; 99(4):361-8.

Iscan 1997 \{published data only\} Iscan HN, Sarisoy L. Comparison of the effects of passive posterior bite-blocks with different construction bites on the craniofacial and dentoalveolar structures. American Journal of Orthodontics and Dentofacial Orthopedics 1997;112(2):171-8.

Jacobs 2002 \{published data only\}

Jacobs T, Sawaengkit P. National Institute of Dental and Craniofacial Research efficacy trials of bionator class II treatment: a review. The Angle Orthodontist 2002;72(6):571-5.

Janson 2003 \{published data only\}

Janson GR, Toruno JL, Martins DR, Henriques JF, de Freitas MR. Class II treatment effects of the Frankel appliance. European Journal of Orthodontics 2003;25(3):301-9.

Jarrell 2001 \{published data only\}

Jarrell KT, Hudson JM, Killiany DM. Activator-Headgear Combination Appliance Treatment of Class II, division I Malocclusion. Journal of Dental Research 2001;80 Special Issue:180 (Abs No 1156). 
Kalra 1989 \{published data only\}

Kalra V, Burstone CJ, Nanda R. Effects of a fixed magnetic appliance on the dentofacial complex. American Journal of Orthodontics and Dentofacial Orthopedics: 1989;95(6):467-78.

Keski-Nisula 2003 \{published data only\}

Keski-Nisula K, Lehto R, Lusa V, Keski-Nisula L, Varrela J. Occurrence of malocclusion and need of orthodontic treatment in early mixed dentition. American Journal of Orthodontics and Dentofacial Orthopedics 2003;124(6):631-8.

Kiliaridis 1990 \{published data only\}

Kiliaridis S, Egermark I, Thilander B. Anterior open bite treatment with magnets.. European Journal of Orthodontics 1990;12(4):44757.

Kluemper 2000 \{published data only\}

Kluemper GT, Beeman CS, Hicks EP. Early orthodontic treatment: what are the imperatives?. Journal of the American Dental Association 2000;131(5):613-20.

Kumar 1996 \{published data only\}

Kumar S, Sidhu SS, Kharbanda OP. A cephalometric evaluation of the dental and facial-skeletal effects using the Bionator with stepwise protrusive activations. The Journal of Clinical Pediatric Dentistry 1996;20(2):101-8.

Lange 1995 \{published data only\}

Lange DW, Kalra V, Broadbent BH Jr, Powers M, Nelson S. Changes in soft tissue profile following treatment with the bionator. The Angle Orthodontist 1995;65(6):423-30.

Lund 1998 \{published data only\}

Lund DI, Sandler PJ. The effects of Twin Blocks: a prospective controlled study. American Journal of Orthodontics and Dentofacial Orthopedics 1998;113(1):104-10.

Malmgren 1987 \{published data only\}

Malmgren O, Omblus J, Hagg U, Pancherz H. Treatment with an orthopedic appliance system in relation to treatment intensity and growth periods. A study of initial effects. American Journal of $\mathrm{Or}$ thodontics and Dentofacial Orthopedics 1987;91(2):143-51.

Mantysaari 2004 \{published data only\}

Mantysaari R, Kantomaa T, Pirttiniemi P, Pykalainen A. The effects of early headgear treatment on dental arches and craniofacial morphology: a report of a 2 year randomized study. European Journal of Orthodontics 2004;26(1):59-64.

\section{Meral 2004 \{published data only\}}

Meral O, Iscan HN, Okay C, Gursoy Y. Effects of bilateral upper first premolar extraction on the mandible. European Journal of $\mathrm{Or}$ thodontics 2004;26(2):223-31.

\section{Muniandy 2000 \{published data only\}}

Muniandy SD, Battagel JM, Moss JP. A prospective study of the twin block and silensor appliances. European Journal of Orthodontics 2000; 22(5):604.

Nelson 2000 \{published data only\}

Nelson B, Hansen K, Hagg U. Class II correction in patients treated with class II elastics and with fixed functional appliances: a comparative study. American Journal of Orthodontics and Dentofacial Orthopedics 2000;118(2):142-9.
Op Heij 1989 \{published and unpublished data\}

Op Heij DG, Callaert H, Opdebeeck HM. The effect of the amount of protrusion built into the bionator on condylar growth and displacement: a clinical study. American Journal of Orthodontics and Dentofacial Orthopedics 1989;95(5):401-9.

Ozturk 1994 \{published data only\}

Ozturk Y, Tankuter N. Class II: a comparison of activator and activator headgear combination appliances. European Journal of $\mathrm{Or}$ thodontics 1994;16(2):149-57.

Pangrazio 1999 \{published data only\}

Pangrazio-Kulbersh V, Berger JL, Chermak DS, Kaczynski R, Simon ES, Haerian A. Treatment effects of the mandibular anterior repositioning appliance on patients with Class II malocclusion. American Journal of Orthodontics and Dentofacial Orthopedics 2003;123(3): 286-95.

* Pangrazio-Kulbersh V, Kaczynski R, Shunock M. Early treatment outcome assessed by the Peer Assessment Rating index. American Journal of Orthodontics and Dentofacial Orthopedics 1999;115(5): 544-50.

Pangrazio 2003 \{published data only\}

Pangrazio-Kulbersh V, Berger JL, Chermak DS, Kaczynski R, Simon ES, Haerian A. Treatment effects of the mandibular anterior repositioning appliance on patients with Class II malocclusion. American Journal of Orthodontics and Dentofacial Orthopedics 2003;123(3): 286-95.

Parkin 2001 \{published data only\}

Parkin NA, McKeown HF, Sandler PJ. Comparison of 2 modifications of the twin-block appliance in matched Class II samples. American Journal of Orthodontics and Dentofacial Orthopedics 2001;119 (6):572-7.

Pennsylvania \{published data only\}

Ghafari J. Class II malocclusion: Comparison of alternative treatments and time of treatment. European Journal of Orthodontics 1999; 21(4):439-40.

Ghafari J, Efstratiadis S, Shofer FS, Markowitz D, et al.Relationship between occlusal and cephalometric changes in the treatment of distocclusion. Journal of Dental Research 1999;78(March Spec Issue): 443 (Abs No 2699).

Ghafari J, Jacobsson-Hunt U, Markowitz DL, Shofer FS, Laster LL. Changes of arch width in the early treatment of Class II, division 1 malocclusions. American Journal of Orthodontics and Dentofacial Orthopedics 1994;106(5):496-502.

Ghafari J, King GJ, Tulloch JF. Early treatment of Class II, division 1 malocclusion--comparison of alternative treatment modalities. Clinical Orthodontics and Research 1998;1(2):107-17.

* Ghafari J, Shofer FS, Jacobsson-Hunt U, Markowitz DL, Laster LL. Headgear versus function regulator in the early treatment of Class II, division 1 malocclusion: a randomized clinical trial. American Journal of Orthodontics and Dentofacial Orthopedics 1998;113(1):5161.

Petrovic 1982 \{published data only\}

Petrovic A, Stutzmann J, Ozerovic B, Vidovic Z. Does the Frankel appliance produce forward movement of mandibular premolars?. European Journal of Orthodontics 1982;4(3):173-83. 
Pirttiniemi 2005 \{published data only\}

Pirttiniemi P, Kantomaa T, Mantysaari R, Pykalainen A. The effects of early headgear treatment on dental arches and craniofacial morphology: an 8 year report of a randomized study. European Journal of Orthodontics 2005;27(5):429-36.

Popowich 2003 \{published data only\}

Popowich K, Nebbe B, Major PW. Effect of Herbst treatment on temporomandibular joint morphology: a systematic literature review. American Journal of Orthodontics and Dentofacial Orthopedics 2003; 123(4):388-94.

Reukers 1998 \{published data only\}

Reukers EA, Sanderink GC, Kuijpers-Jagtman AM, van't Hof MA. Radiographic evaluation of apical root resorption with 2 different types of edgewise appliances. Results of a randomized clinical trial. Journal of Orofacial Orthopedics 1998;59(2):100-9.

\section{Sari 2003 \{published data only\}}

Sari Z, Goyenc Y, Doruk C, Usumez S. Comparative evaluation of a new removable Jasper Jumper functional appliance vs an activatorheadgear combination. The Angle Orthodontist 2003;73(3):286-93.

Schaefer 2004 \{published data only\}

Schaefer AT, McNamara JA Jr, Franchi L, Baccetti T. A cephalometric comparison of treatment with the Twin-block and stainless steel crown Herbst appliances followed by fixed appliance therapy. American Journal of Orthodontics and Dentofacial Orthopedics 2004;126 (1):7-15.

Shannon 2004 \{published data only\}

Shannon KR, Nanda RS. Changes in the curve of Spee with treatment and at 2 years posttreatment. American Journal of Orthodontics and Dentofacial Orthopedics 2004;125(5):589-96.

Taner 2003 \{published data only\}

Taner TU, Yukay F, Pehlivanoglu M, Cakirer B. A comparative analysis of maxillary tooth movement produced by cervical headgear and pend-x appliance. The Angle Orthodontist 2003;73(6):686-91.

Thuer 1989 \{published data only\}

Thuer U, Ingervall B, Burgin W. Does the mandible alter its functional position during activator treatment?. American Journal of $\mathrm{Or}$ thodontics and Dentofacial Orthopedics 1989;96(6):477-84.

Tulloch 1990 \{published data only\}

* Tulloch JF, Medland W, Tuncay OC. Methods used to evaluate growth modification in Class II malocclusion. American Journal of Orthodontics and Dentofacial Orthopedics 1990;98(4):340-7.

Tuncay OC, Tulloch JF. Apparatus criticus: methods used to evaluate growth modification in Class II malocclusion. American Journal of Orthodontics and Dentofacial Orthopedics 1992;102(6):531-6.

Tumer 1999 \{published data only\}

Tumer N, Gultan AS. Comparison of the effects of monoblock and twin-block appliances on the skeletal and dentoalveolar structures. American Journal of Orthodontics and Dentofacial Orthopedics 1999; $116(4): 460-8$.
Ucem 1998 \{published data only\}

Ucem TT, Yuksel S. Effects of different vectors of forces applied by combined headgear. American Journal of Orthodontics and Dentofacial Orthopedics 1998;113(3):316-23.

Ucuncu 2001 \{published and unpublished data\}

Ucuncu N, Turk T, Carels C. Comparison of modified Teuscher and van Beek functional appliance therapies in high-angle cases. Journal of Orofacial Orthopedics 2001;62(3):224-37.

Wieslander 1984 \{published data only\}

Wieslander L. Intensive treatment of severe Class II malocclusions with a headgear-Herbst appliance in the early mixed dentition. American Journal of Orthodontics 1984;86(1):1-13.

Witt 1999 \{published data only\}

Witt E, Watted N. Effectiveness of intra- and extraoral aids to the bionator. A controlled study within the scope of the "Wuerzburg concept". Journal of Orofacial Orthopedics 1999;60(4):269-78.

\section{Additional references}

\section{El-Mangoury 1990}

El-Mangoury NH, Mostafa YA. Epidemiologic panorama of dental occlusion. The Angle Orthodontist 1990;60(3):207-14.

\section{Holmes 1992}

Holmes A. The prevalence of orthodontic treatment need. British Journal of Orthodontics 1992;19(3):177-82.

Landis 1977

Landis JR, Koch GG. The measurement of observer agreement for categorical data. Biometrics 1977;33(1):159-74.

\section{Nguyen 1999}

Nguyen QV, Bezemer PD, Habets L, Prahl-Andersen B. A systematic review of the relationship between overjet size and traumatic dental injuries. European Journal of Orthodontics 1999;21(5):503-15.

Proffit 1993

Proffit WR, Fields HW Jr. Contemporary Orthodontics. 2nd Edition. St Louis, USA: Mosby-Year Book, Inc, 1993:2-16. [: ISBN 08016-6393-8]

Shaw 1980

Shaw WC, Addy M, Ray C. Dental and social effects of malocclusion and effectiveness of orthodontic treatment: a review. Community Dentistry and Oral Epidemiology 1980;8(1):36-45.

Shaw 1991

Shaw WC, Richmond S, O’Brien KD, Brook P, Stephens CD. Quality control in orthodontics: indices of treatment need and treatment standards. British Dental Journal 1991;170(3):107-12.

\section{Silva 2001}

Silva RG, Kang DS. Prevalence of malocclusion among Latino adolescents. American Journal of Orthodontics and Dentofacial Orthopedics 2001;119(3):313-5.

* Indicates the major publication for the study 


\section{CHARACTERISTICS OF STUDIES}

\section{Characteristics of included studies [ordered by study ID]}

\section{Cura 1997}

\begin{tabular}{|c|c|c|}
\hline Methods & \multicolumn{2}{|c|}{$\begin{array}{l}\text { Randomised parallel group study carried out in Turkey. Treatment duration } 6 \text { months. Unclear on blind } \\
\text { assessment. Unclear information on withdrawals. Drop outs: } 21 \% \text {. }\end{array}$} \\
\hline Participants & \multicolumn{2}{|c|}{$\begin{array}{l}\text { Children in clinic with Class II Division } 1 \text { malocclusion, defined by class II molar relationship and ANB } \\
\text { difference of } 5 \text { degrees. } 60 \text { enrolled and } 47 \text { completed. }\end{array}$} \\
\hline Interventions & \multicolumn{2}{|c|}{2 groups (i) Bass functional appliance (ii) untreated control. } \\
\hline Outcomes & \multicolumn{2}{|c|}{ (i) Skeletal discrepancy measured by ANB. } \\
\hline \multicolumn{3}{|l|}{ Notes } \\
\hline \multicolumn{3}{|l|}{ Risk of bias } \\
\hline Item & Authors' judgement & Description \\
\hline Allocation concealment? & Unclear & B - Unclear \\
\hline
\end{tabular}

\section{Florida}

\begin{tabular}{|c|c|c|}
\hline Methods & \multicolumn{2}{|c|}{$\begin{array}{l}\text { Randomised parallel group study over } 10 \text { years. Assessor blind. Clear information on withdrawals. Drop } \\
\text { outs: } 24 \% \text {. }\end{array}$} \\
\hline Participants & \multicolumn{2}{|c|}{ Screened child population then referred to clinic for treatment. 276 enrolled and 68 dropped out. } \\
\hline Interventions & \multicolumn{2}{|c|}{$\begin{array}{l}3 \text { groups (i) delayed treatment control (ii) Bionator appliance (ii) cervical pull headgear with removable } \\
\text { biteplane. }\end{array}$} \\
\hline Outcomes & \multicolumn{2}{|c|}{ (i) Overjet (ii) skeletal discrepancy (iii) dental alignment measured with the PAR index. } \\
\hline Notes & & \\
\hline \multicolumn{3}{|l|}{ Risk of bias } \\
\hline Item & Authors' judgement & Description \\
\hline Allocation concealment? & Yes & A - Adequate \\
\hline
\end{tabular}


London

\begin{tabular}{|c|c|c|}
\hline Methods & \multicolumn{2}{|c|}{$\begin{array}{l}\text { Randomised parallel group study over } 9 \text { months conducted in the UK. Assessor not blinded. Clear } \\
\text { information on withdrawals. Drop outs: } 21 \% \text {. }\end{array}$} \\
\hline Participants & \multicolumn{2}{|c|}{$\begin{array}{l}\text { Children aged } 8-15 \text { years old with Class II Division } 1 \text { malocclusion and an overjet greater than } 7 \mathrm{~mm} .39 \\
\text { enrolled and } 31 \text { completed. }\end{array}$} \\
\hline Interventions & \multicolumn{2}{|c|}{3 groups (i) Bass appliance (ii) Bionator appliance (iii) Twin Block appliance. } \\
\hline Outcomes & \multicolumn{2}{|c|}{ (i) Overjet (ii) skeletal discrepancy - ANB method unclear (iii) soft tissue variables. } \\
\hline Notes & & \\
\hline \multicolumn{3}{|l|}{ Risk of bias } \\
\hline Item & Authors' judgement & Description \\
\hline Allocation concealment? & Unclear & B - Unclear \\
\hline
\end{tabular}

\section{Mao 1997}

\begin{tabular}{|c|c|c|}
\hline Methods & \multicolumn{2}{|c|}{$\begin{array}{l}\text { Randomised parallel group study carried out in China over } 18 \text { months of treatment. Unclear on blinding } \\
\text { Drop outs: } 0 \% \text {. }\end{array}$} \\
\hline Participants & \multicolumn{2}{|c|}{ Children aged 8-11 years old with Class II Division 1 malocclusion. 54 enrolled and 54 completed. } \\
\hline Interventions & \multicolumn{2}{|c|}{2 groups (i) Bionator/headgear appliance (ii) no treatment control. } \\
\hline Outcomes & \multicolumn{2}{|c|}{ Skeletal discrepancy measured by ANB. } \\
\hline \multicolumn{3}{|l|}{ Notes } \\
\hline \multicolumn{3}{|l|}{ Risk of bias } \\
\hline Item & Authors' judgement & Description \\
\hline Allocation concealment? & Unclear & B - Unclear \\
\hline
\end{tabular}

\section{New Zealand}

Methods
Randomised parallel group study carried out in New Zealand over 18 months of treatment. Assessor blind.
Unclear reporting on withdrawals. Drop outs: $23 \%$. 18-month follow up of 3 parallel groups with 50
children in total.




\section{New Zealand (Continued)}

\begin{tabular}{|c|c|c|}
\hline Interventions & \multicolumn{2}{|c|}{3 groups (i) Harvold functional appliance (ii) Frankel functional appliance (iii) untreated control group. } \\
\hline Outcomes & \multicolumn{2}{|c|}{ (i) Change in skeletal pattern represented by ANB (ii) change in overjet (iii) PAR score. } \\
\hline \multicolumn{3}{|l|}{ Notes } \\
\hline \multicolumn{3}{|l|}{ Risk of bias } \\
\hline Item & Authors' judgement & Description \\
\hline Allocation concealment? & Unclear & B - Unclear \\
\hline
\end{tabular}

\section{North Carolina}

\begin{tabular}{|c|c|c|}
\hline Methods & \multicolumn{2}{|c|}{$\begin{array}{l}\text { Randomised parallel group study carried out the in the USA. Treatment provided for } 15 \text { months. Assessor } \\
\text { blind. Clear information on withdrawals. Drop outs: } 21 \% \text {. }\end{array}$} \\
\hline Participants & \multicolumn{2}{|c|}{ Children in the mixed dentition with overjet greater than $7 \mathrm{~mm} .175$ children enrolled and 137 completed. } \\
\hline Interventions & \multicolumn{2}{|c|}{3 groups (i) Bionator appliance (ii) cervical pull headgear (iii) delayed treatment control. } \\
\hline Outcomes & \multicolumn{2}{|c|}{$\begin{array}{l}\text { (i) Overjet (ii) skeletal discrepancy measured by ANB (iii) dental alignment measured with the PAR index } \\
\text { (iv) treatment duration (v) incidence of incisal trauma. }\end{array}$} \\
\hline \multicolumn{3}{|l|}{ Notes } \\
\hline \multicolumn{3}{|l|}{ Risk of bias } \\
\hline Item & Authors' judgement & Description \\
\hline Allocation concealment? & Unclear & B - Unclear \\
\hline
\end{tabular}

\section{UK (11-14)}

Methods

Randomised parallel group multicentre study carried out in the UK. Assessor blind. Clear information on withdrawals. Drop outs: $25 \%$. Included 215 children in 2 groups. 32 dropped out.

Participants Children aged 11-14 with overjets greater than $7 \mathrm{~mm} .215$ enrolled and 151 completed.

Interventions 2 groups (i) Herbst appliance (ii) Twin Block appliance. Followed by fixed appliance treatment, if necessary.

Outcomes $\quad$ (i) Overjet (ii) skeletal discrepancy measured by Pancherz analysis (iii) dental alignment measured with the PAR index and (iv) duration of treatment. 
UK (11-14) (Continued)

\begin{tabular}{|c|c|c|}
\hline Notes & \multicolumn{2}{|c|}{ Quality assessed independently by Helen Worthington. } \\
\hline \multicolumn{3}{|l|}{ Risk of bias } \\
\hline Item & Authors' judgement & Description \\
\hline Allocation concealment? & Yes & A - Adequate \\
\hline \multicolumn{3}{|l|}{ UK (Mixed) } \\
\hline Methods & \multicolumn{2}{|c|}{$\begin{array}{l}\text { Randomised parallel group multicentre trial carried out in the UK over } 15 \text { months. Assessor blinded to } \\
\text { outcomes. Clear information on withdrawals. Drop outs }<1 \% \text {. }\end{array}$} \\
\hline Participants & \multicolumn{2}{|c|}{ Children in the mixed dentition with overjets greater than $7 \mathrm{~mm} .176$ patients enrolled and 173 completed. } \\
\hline Interventions & \multicolumn{2}{|c|}{2 groups (i) Twin Block (ii) delayed treatment. } \\
\hline Outcomes & \multicolumn{2}{|c|}{$\begin{array}{l}\text { (i) Overjet (ii) skeletal discrepancy measured by Pancherz analysis (iii) dental alignment measured with } \\
\text { the PAR index (iv) socio-psychological effects of treatment. }\end{array}$} \\
\hline Notes & \multicolumn{2}{|c|}{ Quality assessed independently by Helen Worthington. } \\
\hline \multicolumn{3}{|l|}{ Risk of bias } \\
\hline Item & Authors' judgement & Description \\
\hline Allocation concealment? & Yes & A - Adequate \\
\hline
\end{tabular}

Characteristics of excluded studies [ordered by study ID]

\begin{tabular}{ll}
\hline Ackerman 2004 & Not CCT/RCT \\
\hline Aelbers 1996 & Literature review. No extra references \\
\hline Aknin 2000 & Method unclear \\
\hline Ashmore 2002 & Not CCT/RCT \\
\hline Banks 2004 & No suitable outcomes
\end{tabular}


(Continued)

\begin{tabular}{|c|c|}
\hline Bishara 1995 & Not CCT/RCT \\
\hline Boecler 1989 & Not CCT/RCT \\
\hline Cevidanes 2003 & No extractable data \\
\hline Chen 2002 & Systematic review. No extra references \\
\hline Chintakanon 2000 & Not outcome of interest \\
\hline Collett 2000 & Not CCT/RCT \\
\hline Cura 1996 & Method unclear \\
\hline Dahan 1989 & Not CCT/RCT \\
\hline De Almeida 2002 & Method unclear \\
\hline DeVincenzo 1989 & Method unclear \\
\hline Du 2002 & Method unclear \\
\hline Erverdi 1995 & $\begin{array}{l}\text { Not CCT/RCT } \\
\text { Contacted authors. No response was received }\end{array}$ \\
\hline Falck 1989 & Method unclear \\
\hline Firouz 1992 & Method unclear \\
\hline Franco 2002 & Not outcome of interest \\
\hline Ghafari 1995 & Not outcome of interest \\
\hline Ghiglione 2000 & Method unclear \\
\hline Gianelly 1983 & Not CCT/RCT \\
\hline Guner 2003 & Method unclear \\
\hline Hagg 2002 & Method unclear \\
\hline Harvold 1971 & Not CCT/RCT \\
\hline Hiyama 2002 & Not CCT/RCT \\
\hline Ingervall 1991 & Method unclear \\
\hline
\end{tabular}


(Continued)

\begin{tabular}{|c|c|}
\hline Iscan 1997 & Not Class II \\
\hline Jacobs 2002 & Systematic review. No extra references \\
\hline Janson 2003 & Not CCT/RCT \\
\hline Jarrell 2001 & Method unclear \\
\hline Kalra 1989 & Method unclear \\
\hline Keski-Nisula 2003 & Not CCT/RCT \\
\hline Kiliaridis 1990 & Not Class II \\
\hline Kluemper 2000 & Review. No extra references \\
\hline Kumar 1996 & Method unclear \\
\hline Lange 1995 & Not CCT/RCT \\
\hline Lund 1998 & Not CCT/RCT \\
\hline Malmgren 1987 & Not CCT/RCT \\
\hline Mantysaari 2004 & Not Class II \\
\hline Meral 2004 & Not Class II \\
\hline Muniandy 2000 & Not Class II \\
\hline Nelson 2000 & Method unclear \\
\hline Op Heij 1989 & Not CCT/RCT \\
\hline Ozturk 1994 & Method unclear \\
\hline Pangrazio 1999 & Methos unclear \\
\hline Pangrazio 2003 & Not CCT/RCT \\
\hline Parkin 2001 & Not CCT/RCT \\
\hline Pennsylvania & Not outcome of interest \\
\hline Petrovic 1982 & Method unclear \\
\hline
\end{tabular}


(Continued)

\begin{tabular}{ll}
\hline Pirttiniemi 2005 & RCT outcomes not relevant to this review \\
\hline Popowich 2003 & Systematic review. No extra references \\
\hline Reukers 1998 & Method unclear \\
\hline Sari 2003 & Method unclear \\
\hline Schaefer 2004 & Not CCT/RCT \\
\hline Shannon 2004 & Not CCT/RCT \\
\hline Taner 2003 & Not outcome of interest \\
\hline Thuer 1989 & Method unclear \\
\hline Tulloch 1990 & Literature review. No extra references \\
\hline Tumer 1999 & Method unclear \\
\hline Ucem 1998 & Method unclear \\
\hline Ucuncu 2001 & Method unclear \\
\hline Wieslander 1984 & Not CCT/RCT \\
\hline Witt 1999 & Method unclear \\
\hline
\end{tabular}

$\mathrm{CCT}=$ controlled clinical trial

$\mathrm{RCT}=$ randomised controlled trial 
DATA AND ANALYSES

Comparison 1. Early treatment at the end of Phase I: functional versus control

\begin{tabular}{lccll} 
Outcome or subgroup title & $\begin{array}{c}\text { No. of } \\
\text { studies }\end{array}$ & $\begin{array}{c}\text { No. of } \\
\text { participants }\end{array}$ & \multicolumn{1}{c}{ Statistical method } & Effect size \\
\hline 1 Final overjet & 3 & 432 & Mean Difference (IV, Random, 95\% CI) & $-4.04[-7.47,-0.60]$ \\
2 Final ANB & 3 & 419 & Mean Difference (IV, Random, 95\% CI) & $-1.35[-2.57,-0.14]$ \\
3 PAR score & 3 & 380 & Mean Difference (IV, Random, 95\% CI) & $-12.63[-22.28,-$ \\
& & & & $2.99]$ \\
4 ANB change & 3 & 318 & Mean Difference (IV, Random, 95\% CI) & $-0.55[-0.92,-0.18]$ \\
5 Self concept & 1 & 135 & Mean Difference (IV, Fixed, 95\% CI) & $3.63[-0.40,7.66]$ \\
$\begin{array}{l}\text { 6 Incidence of incisal trauma } \\
\quad \text { during Phase I treatment }\end{array}$ & 1 & 113 & Odds Ratio (M-H, Random, 95\% CI) & $0.31[0.11,0.86]$ \\
\hline
\end{tabular}

Comparison 2. Early treatment at the end of Phase I: headgear versus control

\begin{tabular}{lcclc} 
Outcome or subgroup title & $\begin{array}{c}\text { No. of } \\
\text { studies }\end{array}$ & $\begin{array}{c}\text { No. of } \\
\text { participants }\end{array}$ & Statistical method & Effect size \\
\hline 1 Final overjet & 2 & 278 & Mean Difference (IV, Random, 95\% CI) & $-1.07[-1.63,-0.51]$ \\
2 Final ANB & 2 & 277 & Mean Difference (IV, Random, 95\% CI) & $-0.72[-1.18,-0.27]$ \\
$\begin{array}{l}\text { Incidence of incisal trauma } \\
\quad \text { during Phase I treatment }\end{array}$ & 1 & 111 & Odds Ratio (M-H, Random, 95\% CI) & $0.52[0.21,1.30]$ \\
\hline
\end{tabular}

Comparison 3. Early treatment at the end of Phase I: headgear versus functional

\begin{tabular}{lcclc} 
Outcome or subgroup title & $\begin{array}{c}\text { No. of } \\
\text { studies }\end{array}$ & $\begin{array}{c}\text { No. of } \\
\text { participants }\end{array}$ & Statistical method & Effect size \\
\hline 1 Final overjet & 2 & 271 & Mean Difference (IV, Random, 95\% CI) & $1.26[-0.92,3.44]$ \\
2 Final ANB & 2 & 271 & Mean Difference (IV, Random, 95\% CI) & $-0.04[-0.49,0.41]$ \\
3 ANB change & 2 & 284 & Mean Difference (IV, Random, 95\% CI) & $0.01[-0.28,0.29]$ \\
$\begin{array}{l}\text { 4 Incidence of incisal trauma } \\
\quad \text { during Phase I treatment }\end{array}$ & 1 & 102 & Odds Ratio (M-H, Fixed, 95\% CI) & $1.68[0.55,5.13]$ \\
\hline
\end{tabular}


Comparison 4. Early treatment at the end of Phase II: functional versus control

\begin{tabular}{lccll} 
Outcome or subgroup title & $\begin{array}{c}\text { No. of } \\
\text { studies }\end{array}$ & $\begin{array}{c}\text { No. of } \\
\text { participants }\end{array}$ & Statistical method & Effect size \\
\hline 1 Final overjet & 3 & 343 & Mean Difference (IV, Random, 95\% CI) & $0.24[-0.32,0.80]$ \\
2 Final ANB & 3 & 347 & Mean Difference (IV, Random, 95\% CI) & $-0.03[-0.55,0.48]$ \\
3 PAR score & 3 & 360 & Mean Difference (IV, Random, 95\% CI) & $0.96[-1.68,3.61]$ \\
4 New incisal trauma during Phase & 1 & 93 & Odds Ratio (M-H, Random, 95\% CI) & $0.40[0.17,0.94]$ \\
$\quad$ II treatment & & & & \\
\hline
\end{tabular}

Comparison 5. Early treatment at the end of Phase II: headgear versus control

\begin{tabular}{lcclc} 
Outcome or subgroup title & $\begin{array}{c}\text { No. of } \\
\text { studies }\end{array}$ & $\begin{array}{c}\text { No. of } \\
\text { participants }\end{array}$ & Statistical method & Effect size \\
\hline 1 Final overjet & 2 & 238 & Mean Difference (IV, Random, 95\% CI) & $-0.24[-0.63,0.16]$ \\
2 Final ANB & 2 & 231 & Mean Difference (IV, Random, 95\% CI) & $-0.27[-0.80,0.26]$ \\
3 PAR score & 2 & 177 & Mean Difference (IV, Random, 95\% CI) & $-1.55[-3.70,0.60]$ \\
4 New incisal trauma during Phase & 1 & 97 & Odds Ratio (M-H, Random, 95\% CI) & $0.25[0.10,0.60]$ \\
$\quad$ II treatment & & & & \\
\hline
\end{tabular}

Comparison 6. Early treatment at the end of Phase II: headgear versus functional

\begin{tabular}{lcclc} 
Outcome or subgroup title & $\begin{array}{c}\text { No. of } \\
\text { studies }\end{array}$ & $\begin{array}{c}\text { No. of } \\
\text { participants }\end{array}$ & Statistical method & Effect size \\
\hline 1 Final overjet & 2 & 225 & Mean Difference (IV, Random, 95\% CI) & $-0.21[-0.57,0.15]$ \\
2 Final ANB & 2 & 222 & Mean Difference (IV, Random, 95\% CI) & $-0.13[-0.78,0.53]$ \\
3 PAR score & 2 & 224 & Mean Difference (IV, Random, 95\% CI) & $-0.81[-2.21,0.58]$ \\
$\begin{array}{l}\text { 4 New incisal trauma during Phase } \\
\quad 1\end{array}$ & 1 & 88 & Odds Ratio (M-H, Random, 95\% CI) & $0.62[0.24,1.62]$ \\
$\quad$ & & & \\
\hline
\end{tabular}

Comparison 7. Adolescent treatment: functional versus control

\begin{tabular}{lccccc} 
Outcome or subgroup title & $\begin{array}{c}\text { No. of } \\
\text { studies }\end{array}$ & $\begin{array}{c}\text { No. of } \\
\text { participants }\end{array}$ & Statistical method & Effect size & \\
\hline 1 Final overjet & 1 & 47 & Mean Difference (IV, Random, 95\% CI) & $-5.22[-6.51,-3.93]$ \\
2 Final ANB & 2 & 99 & Mean Difference (IV, Random, 95\% CI) & $-2.27[-3.22,-1.31]$ \\
\hline
\end{tabular}


Comparison 8. Adolescent treatment: Twin Block versus other functional appliances

\begin{tabular}{lcccc} 
Outcome or subgroup title & $\begin{array}{c}\text { No. of } \\
\text { studies }\end{array}$ & $\begin{array}{c}\text { No. of } \\
\text { participants }\end{array}$ & Statistical method & Effect size \\
\hline 1 Final ANB & 2 & 155 & Mean Difference (IV, Random, 95\% CI) & $-0.68[-1.32,-0.04]$ \\
2 Final overjet & 2 & 164 & Mean Difference (IV, Random, 95\% CI) & $0.47[-0.12,1.06]$ \\
\hline
\end{tabular}

Analysis I.I. Comparison I Early treatment at the end of Phase I: functional versus control, Outcome I Final overjet.

Review: Orthodontic treatment for prominent upper front teeth in children

Comparison: | Early treatment at the end of Phase l: functional versus control

Outcome: I Final overjet

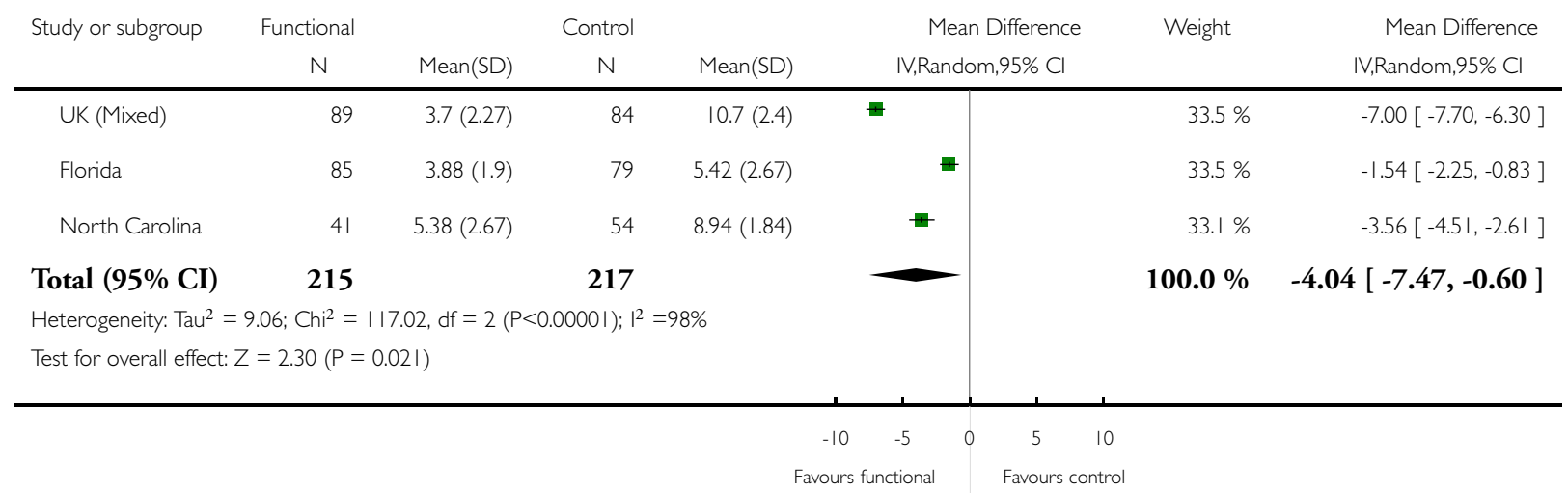


Analysis I.2. Comparison I Early treatment at the end of Phase I: functional versus control, Outcome 2 Final ANB.

Review: Orthodontic treatment for prominent upper front teeth in children

Comparison: I Early treatment at the end of Phase I: functional versus control

Outcome: 2 Final ANB

\begin{tabular}{|c|c|c|c|c|c|c|c|}
\hline \multirow[t]{2}{*}{ Study or subgroup } & \multirow{2}{*}{$\begin{array}{c}\text { Functional } \\
\qquad \mathrm{N}\end{array}$} & \multicolumn{3}{|c|}{ Control } & \multirow{2}{*}{$\begin{array}{l}\text { Mean Difference } \\
\text { IV,Random,95\% Cl }\end{array}$} & \multirow[t]{2}{*}{ Weight } & \multirow{2}{*}{$\begin{array}{l}\text { Mean Difference } \\
\text { IV,Random,95\% Cl }\end{array}$} \\
\hline & & Mean(SD) & $\mathrm{N}$ & Mean(SD) & & & \\
\hline Florida & 85 & $3.96(1.95)$ & 78 & $4.49(2.19)$ & $+\mathrm{F}$ & $40.3 \%$ & $-0.53[-1.17,0.11]$ \\
\hline North Carolina & 41 & $4.82(2.08)$ & 54 & $5.77(2.08)$ & 풀 & $37.2 \%$ & $-0.95[-1.79,-0.11]$ \\
\hline UK (Mixed) & 87 & $3.85(1.8)$ & 74 & $7.35(7.8)$ & $\square$ & $22.5 \%$ & $-3.50[-5.32,-1.68]$ \\
\hline
\end{tabular}

Total (95\% CI)

213

206

$100.0 \%-1.35[-2.57,-0.14]$

Heterogeneity: $\mathrm{Tau}^{2}=0.84 ; \mathrm{Chi}^{2}=9.17, \mathrm{df}=2(\mathrm{P}=0.0 \mathrm{I}) ; \mathrm{I}^{2}=78 \%$

Test for overall effect: $Z=2.19(P=0.029)$

\begin{tabular}{llllll}
-10 & -5 & 0 & 5 & 10 \\
\hline & Favours functional & Favours control
\end{tabular}

Analysis I.3. Comparison I Early treatment at the end of Phase I: functional versus control, Outcome 3 PAR score.

Review: Orthodontic treatment for prominent upper front teeth in children

Comparison: I Early treatment at the end of Phase l: functional versus control

Outcome: 3 PAR score

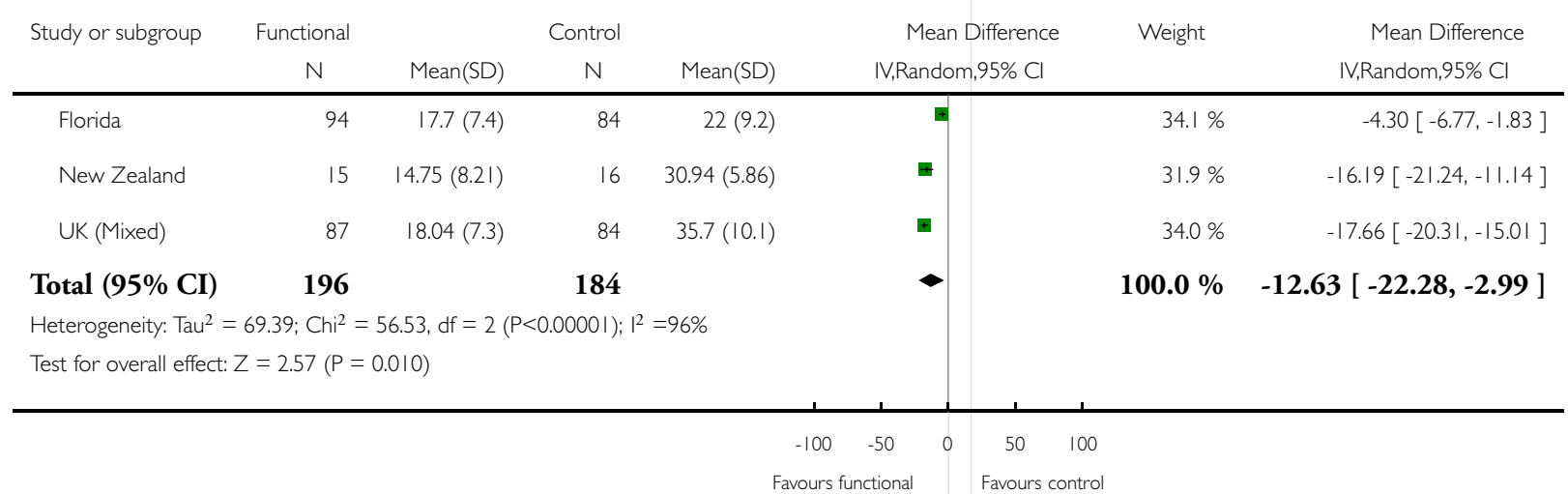


Analysis I.4. Comparison I Early treatment at the end of Phase I: functional versus control, Outcome 4 ANB change.

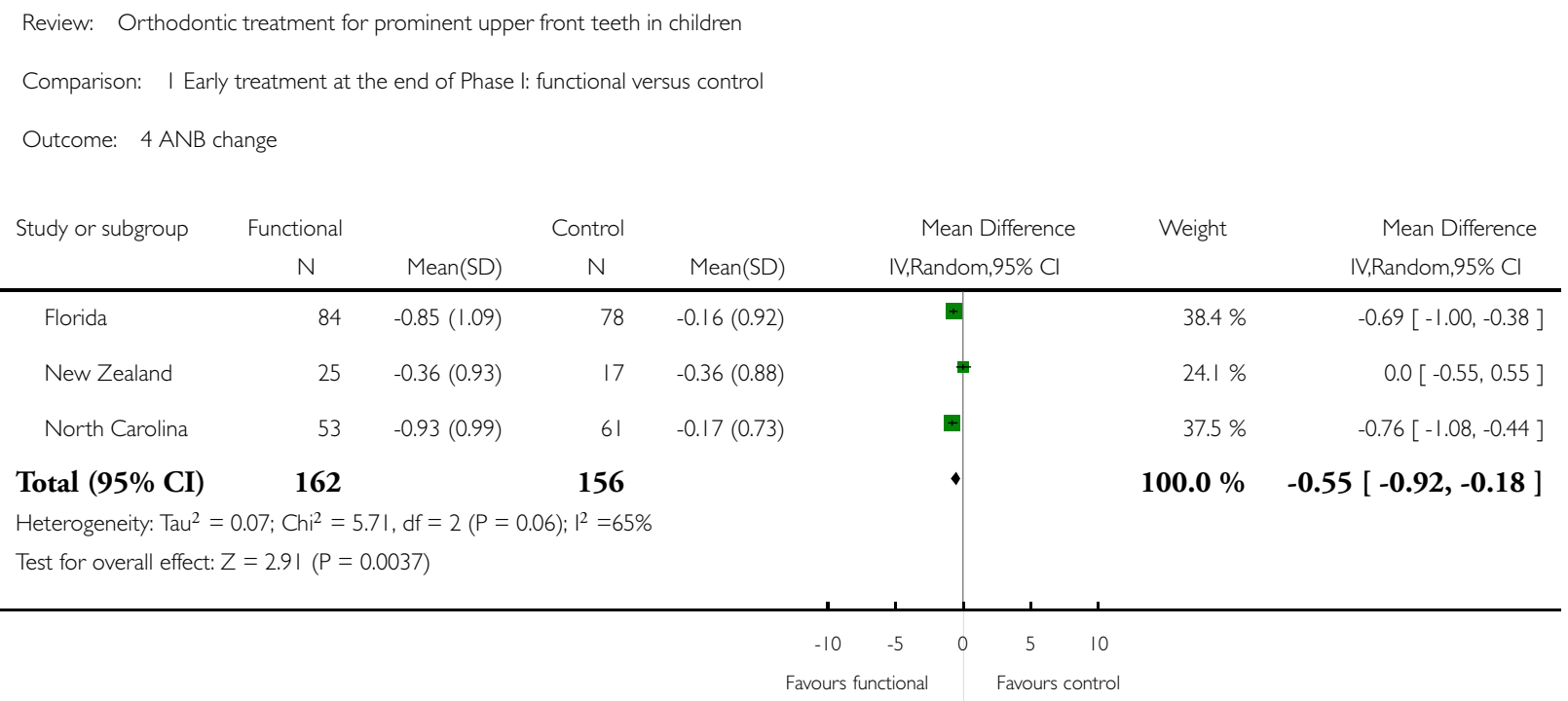

Analysis I.5. Comparison I Early treatment at the end of Phase I: functional versus control, Outcome 5 Self concept.

Review: Orthodontic treatment for prominent upper front teeth in children

Comparison: | Early treatment at the end of Phase l: functional versus control

Outcome: 5 Self concept

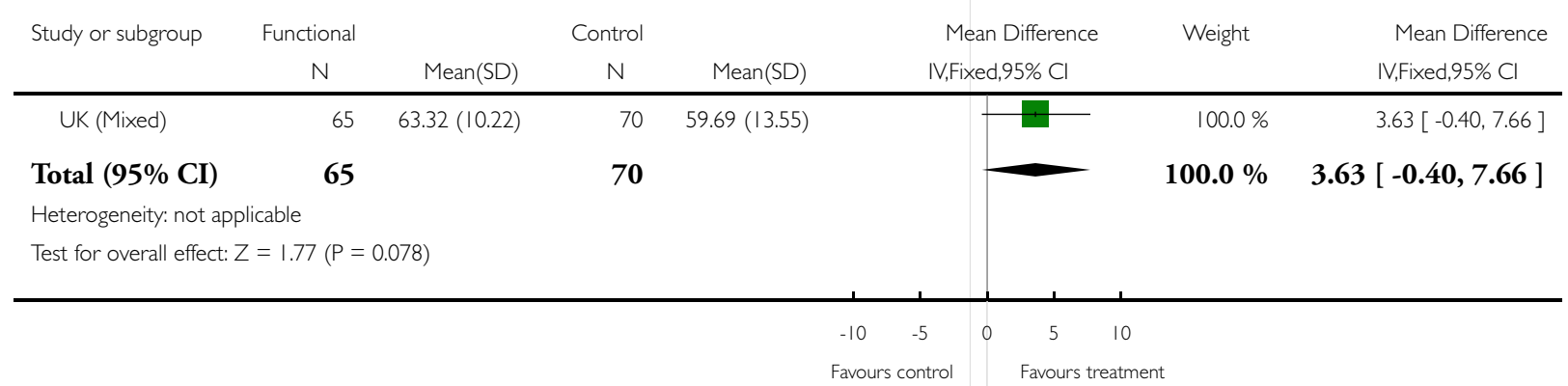


Analysis I.6. Comparison I Early treatment at the end of Phase I: functional versus control, Outcome 6 Incidence of incisal trauma during Phase I treatment.

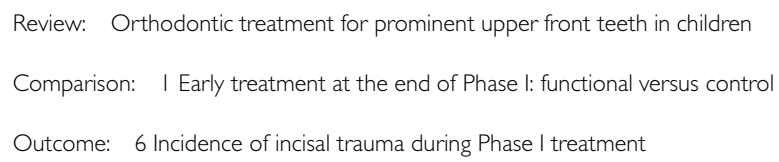

\section{Analysis 2.I. Comparison 2 Early treatment at the end of Phase I: headgear versus control, Outcome I} Final overjet.

Review: Orthodontic treatment for prominent upper front teeth in children

Comparison: 2 Early treatment at the end of Phase l: headgear versus control

Outcome: I Final overjet

\begin{tabular}{|c|c|c|c|c|c|c|c|}
\hline \multirow[t]{2}{*}{ Study or subgroup } & Headgear & \multicolumn{3}{|c|}{ Control } & \multirow{2}{*}{$\begin{array}{l}\text { Mean Difference } \\
\text { IV,Random,95\% Cl }\end{array}$} & \multirow[t]{2}{*}{ Weight } & \multirow{2}{*}{$\begin{array}{l}\text { Mean Difference } \\
\text { IV,Random,95\% Cl }\end{array}$} \\
\hline & $N$ & Mean(SD) & $N$ & Mean(SD) & & & \\
\hline Florida & 95 & $3.99(2.33)$ & 79 & $5(2.67)$ & + & $55.8 \%$ & $-1.01[-1.76,-0.26]$ \\
\hline North Carolina & 50 & $7.8(2.48)$ & 54 & $8.94(1.84)$ & \# & $44.2 \%$ & $-1.14[-1.98,-0.30]$ \\
\hline
\end{tabular}

Total (95\% CI) $145 \quad 133$

Heterogeneity: $\mathrm{Tau}^{2}=0.0 ; \mathrm{Chi}^{2}=0.05, \mathrm{df}=\mathrm{I}(\mathrm{P}=0.82) ; \mathrm{I}^{2}=0.0 \%$

Test for overall effect: $Z=3.72(P=0.00020)$ 
Analysis 2.2. Comparison 2 Early treatment at the end of Phase I: headgear versus control, Outcome 2 Final ANB.

Review: Orthodontic treatment for prominent upper front teeth in children

Comparison: 2 Early treatment at the end of Phase l: headgear versus control

Outcome: 2 Final ANB

\begin{tabular}{|c|c|c|c|c|c|c|c|}
\hline \multirow[t]{2}{*}{ Study or subgroup } & Headgear & \multicolumn{3}{|c|}{ Control } & Mean Difference & \multirow[t]{2}{*}{ Weight } & \multirow{2}{*}{$\begin{array}{l}\text { Mean Difference } \\
\text { IV,Random,95\% Cl }\end{array}$} \\
\hline & $\mathrm{N}$ & Mean(SD) & $N$ & Mean(SD) & IV,Random,95\% Cl & & \\
\hline Florida & 95 & $3.89(1.85)$ & 78 & $4.49(2.19)$ & 푼 & $55.0 \%$ & $-0.60[-1.21,0.01]$ \\
\hline North Carolina & 50 & $4.83(1.5)$ & 54 & $5.7(2)$ & 무 & $45.0 \%$ & $-0.87[-1.55,-0.19]$ \\
\hline
\end{tabular}

Total (95\% CI) 145

Heterogeneity: $\mathrm{Tau}^{2}=0.0 ; \mathrm{Chi}^{2}=0.34, \mathrm{df}=\mathrm{I}(\mathrm{P}=0.56) ; \mathrm{I}^{2}=0.0 \%$

Test for overall effect: $Z=3.12(P=0.0018)$

$\begin{array}{lllll}-10 & -5 & 0 & 5 & 10\end{array}$

Favours headgear Favours control

Analysis 2.3. Comparison 2 Early treatment at the end of Phase I: headgear versus control, Outcome 3 Incidence of incisal trauma during Phase I treatment.

Review: Orthodontic treatment for prominent upper front teeth in children

Comparison: 2 Early treatment at the end of Phase l: headgear versus control

Outcome: 3 Incidence of incisal trauma during Phase I treatment

\begin{tabular}{|c|c|c|c|c|c|c|}
\hline \multirow[t]{2}{*}{ Study or subgroup } & Headgear & Control & \multicolumn{2}{|r|}{ Odds Ratio } & \multirow[t]{2}{*}{ Weight } & \multirow{2}{*}{$\begin{array}{c}\text { Odds Ratio } \\
\mathrm{M}-\mathrm{H}, \text { Random,95\% Cl}\end{array}$} \\
\hline & $\mathrm{n} / \mathrm{N}$ & $\mathrm{n} / \mathrm{N}$ & & M-H,Random,95\% Cl & & \\
\hline North Carolina & $9 / 50$ & $|8 / 6|$ & & + & $100.0 \%$ & $0.52[0.21,1.30]$ \\
\hline Total (95\% CI) & 50 & 61 & & & $100.0 \%$ & $0.52[0.21,1.30]$ \\
\hline \multicolumn{7}{|c|}{ Total events: 9 (Headgear), I 8 (Control) } \\
\hline \multicolumn{7}{|c|}{ Heterogeneity: not applicable } \\
\hline \multicolumn{7}{|c|}{ Test for overall effect: $Z=1.39(P=0.16)$} \\
\hline
\end{tabular}


Analysis 3.I. Comparison 3 Early treatment at the end of Phase I: headgear versus functional, Outcome I Final overjet.

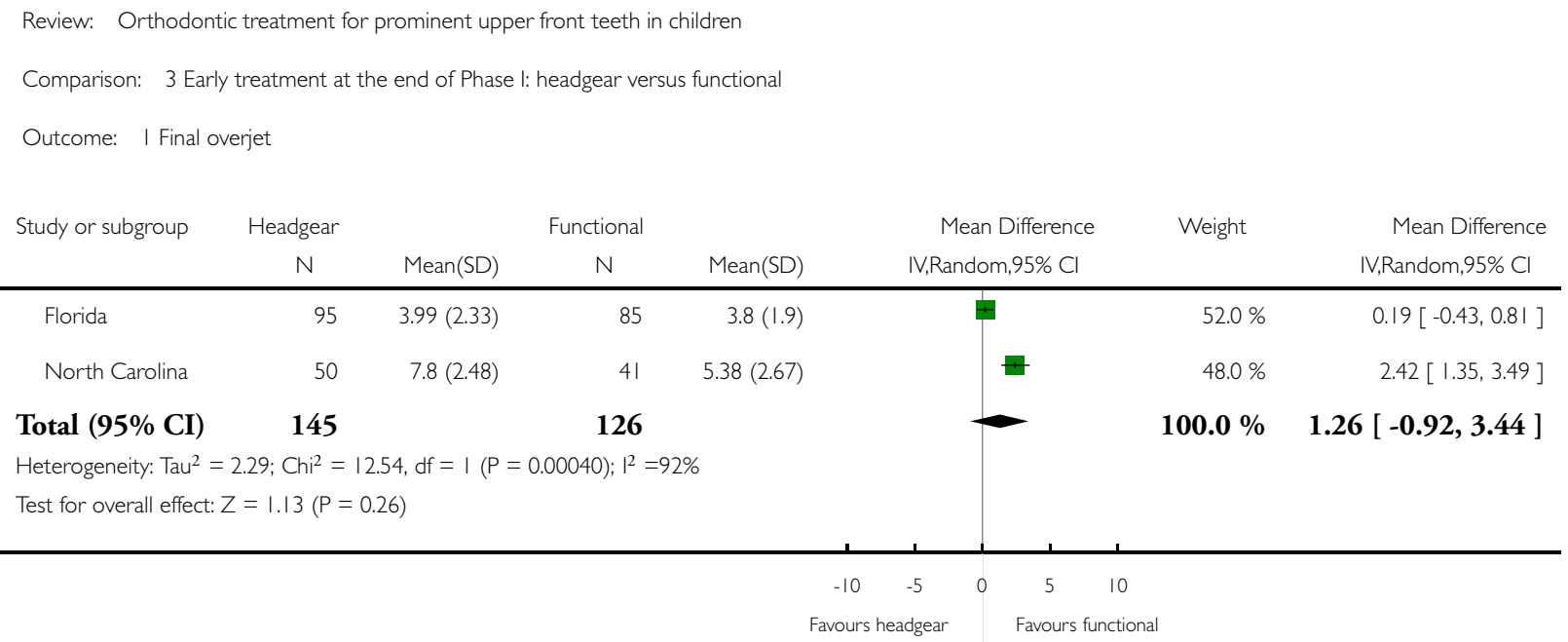

Analysis 3.2. Comparison 3 Early treatment at the end of Phase I: headgear versus functional, Outcome 2 Final ANB.

Review: Orthodontic treatment for prominent upper front teeth in children

Comparison: 3 Early treatment at the end of Phase l: headgear versus functional

Outcome: 2 Final ANB

\begin{tabular}{|c|c|c|c|c|c|c|c|}
\hline \multirow[t]{2}{*}{ Study or subgroup } & \multirow{2}{*}{$\begin{array}{c}\text { Headgear } \\
\mathrm{N}\end{array}$} & \multicolumn{3}{|c|}{ Functional } & \multirow{2}{*}{$\begin{array}{l}\text { Mean Difference } \\
\text { IV,Random,95\% Cl }\end{array}$} & \multirow[t]{2}{*}{ Weight } & \multirow{2}{*}{$\begin{array}{l}\text { Mean Difference } \\
\text { IV,Random,95\% Cl }\end{array}$} \\
\hline & & Mean(SD) & $\mathrm{N}$ & Mean(SD) & & & \\
\hline Florida & 95 & $3.89(1.85)$ & 85 & $3.96(1.95)$ & + & $65.1 \%$ & $-0.07[-0.63,0.49]$ \\
\hline North Carolina & 50 & $4.83(1.5)$ & 41 & $4.82(2.08)$ & \# & $34.9 \%$ & $0.01[-0.75,0.77]$ \\
\hline
\end{tabular}

Total (95\% CI)

145

126

$100.0 \% \quad-0.04[-0.49,0.41]$

Heterogeneity: $\mathrm{Tau}^{2}=0.0 ; \mathrm{Chi}^{2}=0.03, \mathrm{df}=\mathrm{I}(\mathrm{P}=0.87) ; \mathrm{I}^{2}=0.0 \%$

Test for overall effect: $Z=0.18(P=0.85)$

$\begin{array}{ccccc}-10 & -5 & 0 & 5 & 10 \\ \text { Favours headgear } & & \text { Favours functional }\end{array}$


Analysis 3.3. Comparison 3 Early treatment at the end of Phase I: headgear versus functional, Outcome 3 ANB change.

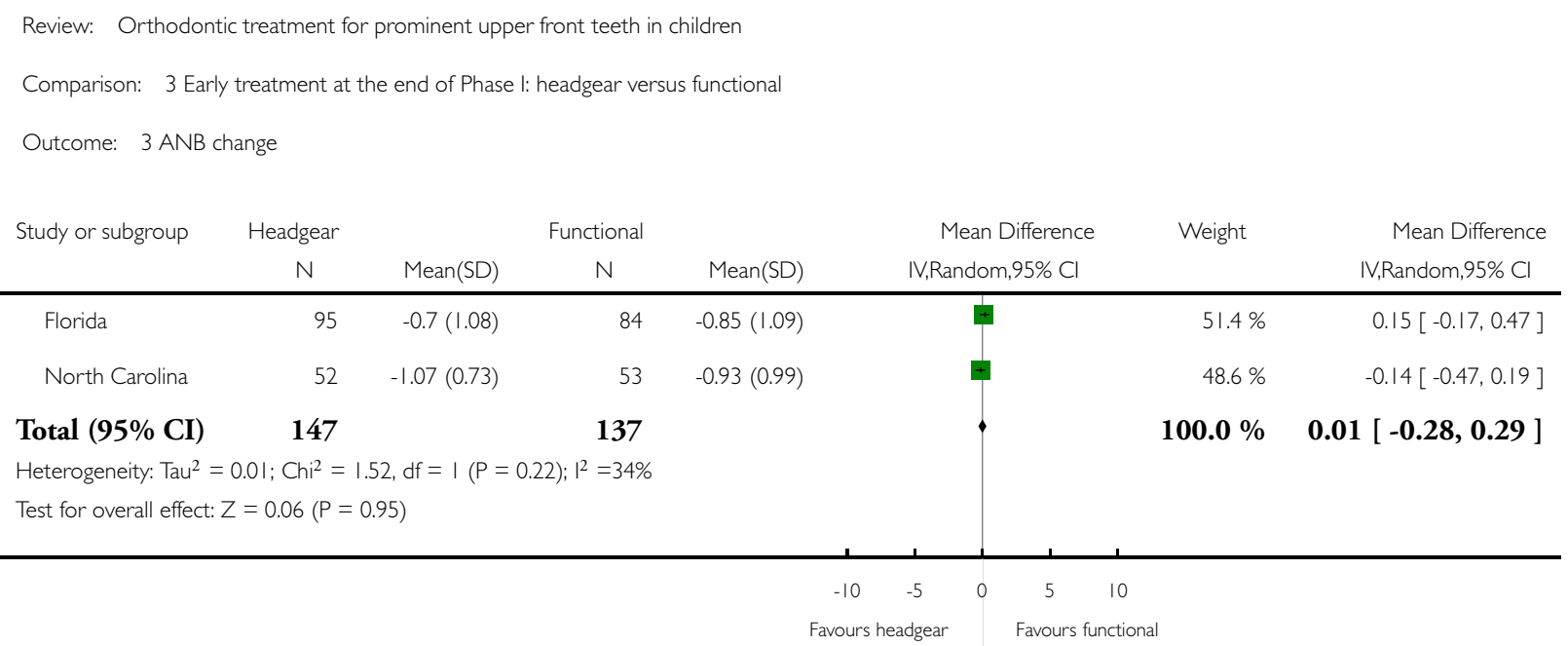

Analysis 3.4. Comparison 3 Early treatment at the end of Phase I: headgear versus functional, Outcome 4 Incidence of incisal trauma during Phase I treatment.

Review: Orthodontic treatment for prominent upper front teeth in children

Comparison: 3 Early treatment at the end of Phase l: headgear versus functional

Outcome: 4 Incidence of incisal trauma during Phase I treatment

\begin{tabular}{|c|c|c|c|c|c|}
\hline Study or subgroup & $\begin{array}{c}\text { Headgear } \\
n / N\end{array}$ & $\begin{array}{c}\text { Functional } \\
n / N\end{array}$ & $\begin{array}{r}\text { Odds Ratio } \\
\text { M-H,Fixed,95\% Cl }\end{array}$ & Weight & $\begin{array}{c}\text { Odds Ratio } \\
\mathrm{M}-\mathrm{H}, \text { Fixed,95\% Cl }\end{array}$ \\
\hline North Carolina & $9 / 50$ & $6 / 52$ & $+\square$ & $100.0 \%$ & $1.68[0.55,5.13]$ \\
\hline Total $(95 \% \mathrm{CI})$ & 50 & 52 & & $100.0 \%$ & $1.68[0.55,5.13]$ \\
\hline \multicolumn{6}{|c|}{ Total events: 9 (Headgear), 6 (Functional) } \\
\hline \multicolumn{6}{|c|}{ Heterogeneity: not applicable } \\
\hline Test for overall effect: & $(P=0.36)$ & & & & \\
\hline
\end{tabular}


Analysis 4.I. Comparison 4 Early treatment at the end of Phase II: functional versus control, Outcome I Final overjet.

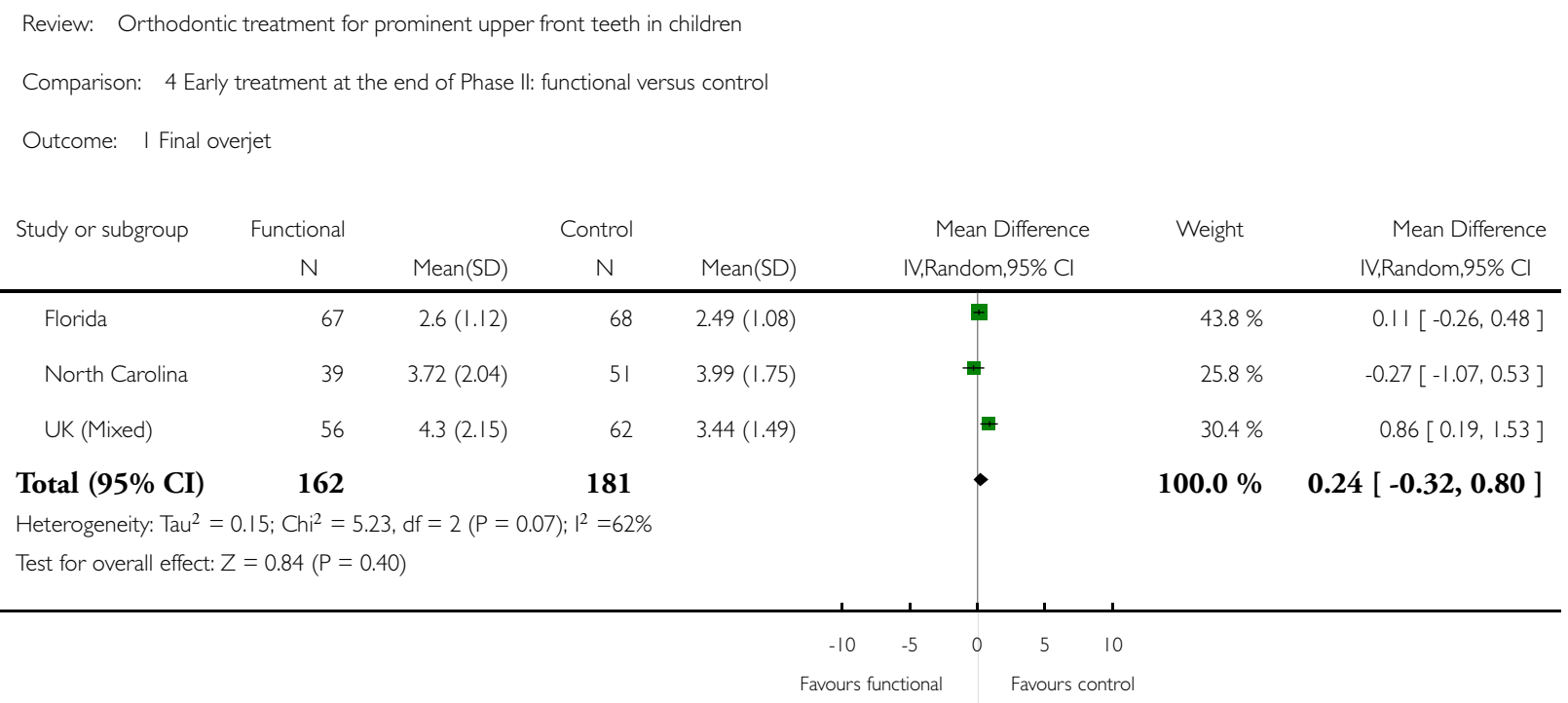

Analysis 4.2. Comparison 4 Early treatment at the end of Phase II: functional versus control, Outcome 2 Final ANB.

Review: Orthodontic treatment for prominent upper front teeth in children

Comparison: 4 Early treatment at the end of Phase II: functional versus control

Outcome: 2 Final ANB

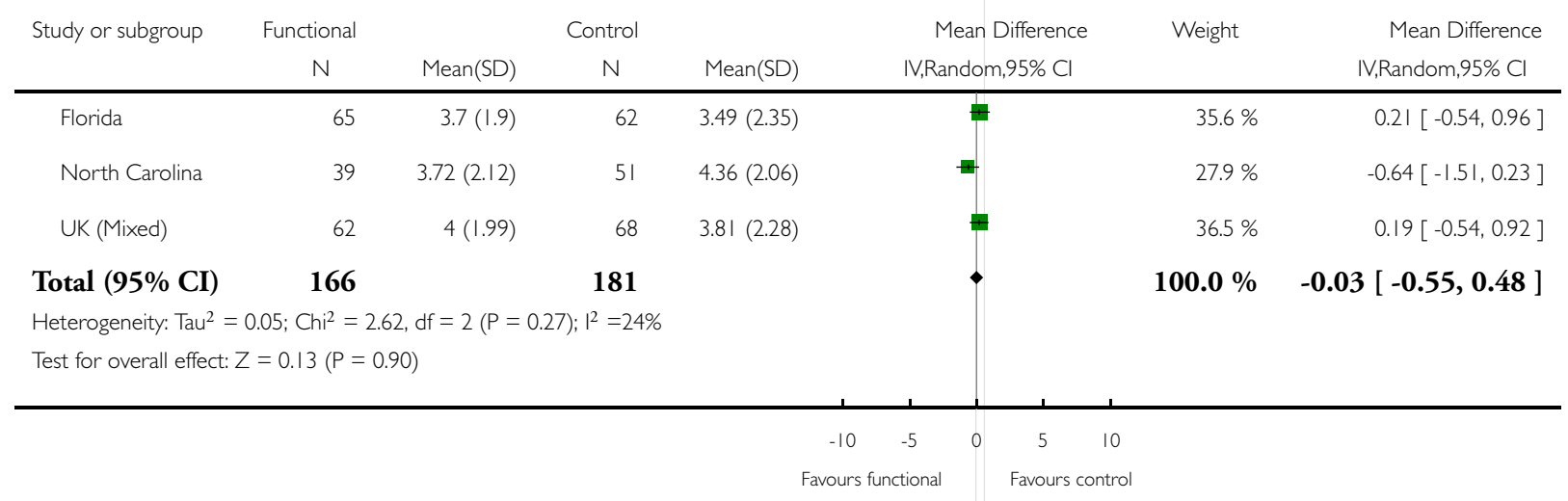


Analysis 4.3. Comparison 4 Early treatment at the end of Phase II: functional versus control, Outcome 3 PAR score.

Review: Orthodontic treatment for prominent upper front teeth in children

Comparison: 4 Early treatment at the end of Phase II: functional versus control

Outcome: 3 PAR score

\begin{tabular}{|c|c|c|c|c|c|c|c|}
\hline \multirow[t]{2}{*}{ Study or subgroup } & \multirow{2}{*}{$\begin{array}{c}\text { Functional } \\
\text { N }\end{array}$} & \multicolumn{3}{|c|}{ Control } & \multirow{2}{*}{$\begin{array}{l}\text { Mean Difference } \\
\text { IV,Random,95\% Cl }\end{array}$} & \multirow[t]{2}{*}{ Weight } & \multirow{2}{*}{$\begin{array}{l}\text { Mean Difference } \\
\text { IV,Random,95\% Cl }\end{array}$} \\
\hline & & Mean(SD) & $\mathrm{N}$ & Mean(SD) & & & \\
\hline Florida & 66 & $6(5)$ & 70 & $6(4.4)$ & $\because$ & $41.6 \%$ & $0.0[-1.59,1.59]$ \\
\hline North Carolina & 39 & $8.4(7.7)$ & 51 & $9.3(8.1)$ & $\longrightarrow$ & $27.9 \%$ & $-0.90[-4.18,2.38]$ \\
\hline UK (Mixed) & 64 & $10.42(10.42)$ & 70 & $6.44(6.23)$ & $\mp$ & $30.5 \%$ & $3.98[1.04,6.92]$ \\
\hline Total (95\% CI) & 169 & & 191 & & & $100.0 \%$ & $0.96[-1.68,3.61]$ \\
\hline
\end{tabular}

Heterogeneity: Tau $^{2}=3.73 ; \mathrm{Chi}^{2}=6.43, \mathrm{df}=2(\mathrm{P}=0.04) ; \mathrm{I}^{2}=69 \%$

Test for overall effect: $Z=0.7 \mathrm{I}(P=0.48)$

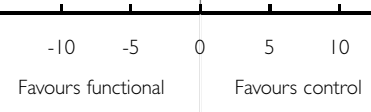

Analysis 4.4. Comparison 4 Early treatment at the end of Phase II: functional versus control, Outcome 4 New incisal trauma during Phase II treatment.

Review: Orthodontic treatment for prominent upper front teeth in children

Comparison: 4 Early treatment at the end of Phase II: functional versus control

Outcome: 4 New incisal trauma during Phase II treatment

\begin{tabular}{|c|c|c|c|c|c|}
\hline \multirow[t]{2}{*}{ Study or subgroup } & Functional & Control & Odds Ratio & Weight & Odds Ratio \\
\hline & $n / N$ & $\mathrm{n} / \mathrm{N}$ & $\mathrm{M}-\mathrm{H}$,Random,95\% Cl & & $\mathrm{M}-\mathrm{H}$, Random, $95 \% \mathrm{Cl}$ \\
\hline North Carolina & $13 / 42$ & $27 / 51$ & 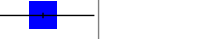 & $100.0 \%$ & $0.40[0.17,0.94]$ \\
\hline Total $(95 \%$ CI $)$ & 42 & 51 & & $100.0 \%$ & $0.40[0.17,0.94]$ \\
\hline
\end{tabular}

Total events: 13 (Functional), 27 (Control)

Heterogeneity: not applicable

Test for overall effect: $Z=2.11(P=0.035)$

$\begin{array}{lllllll}0.1 & 0.2 & 0.5 & 1 & 2 & 5 & 10\end{array}$

Favours treatment Favours control 
Analysis 5.I. Comparison 5 Early treatment at the end of Phase II: headgear versus control, Outcome I Final overjet.

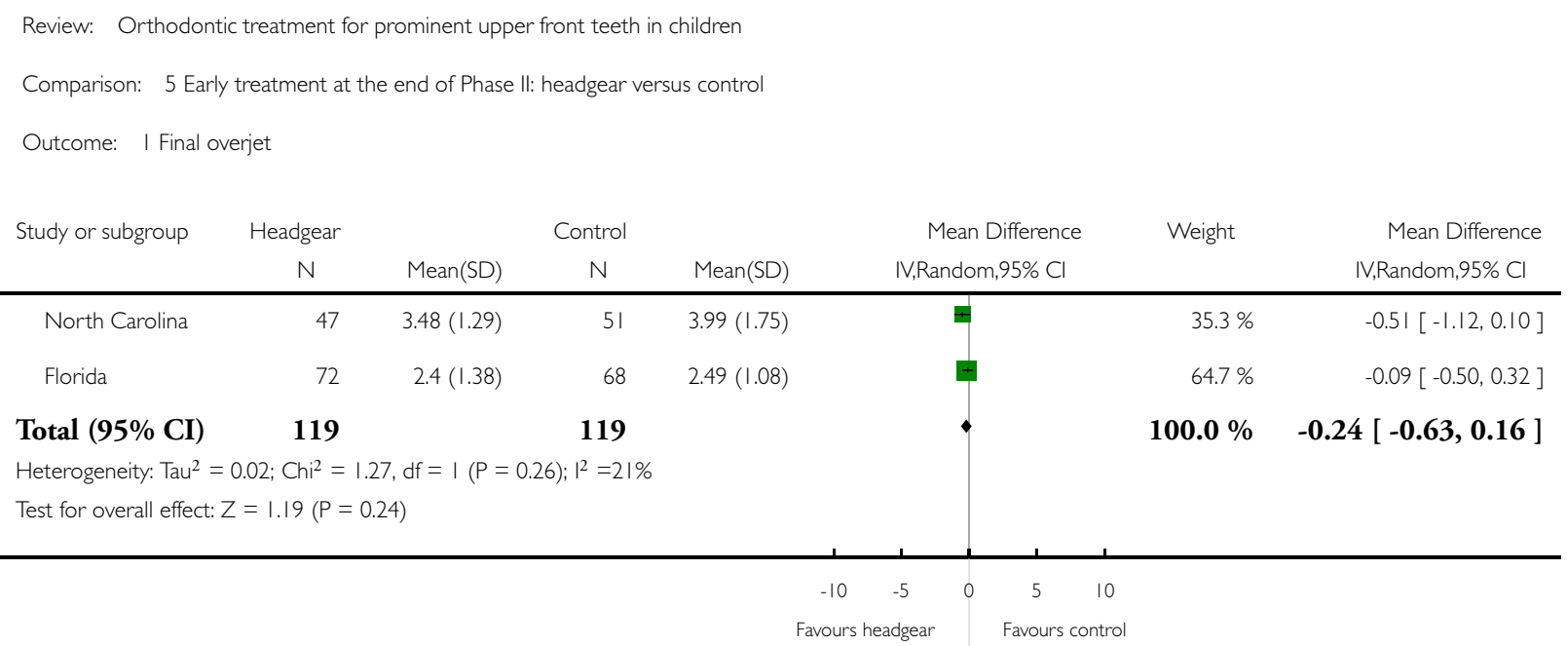

Analysis 5.2. Comparison 5 Early treatment at the end of Phase II: headgear versus control, Outcome 2 Final ANB.

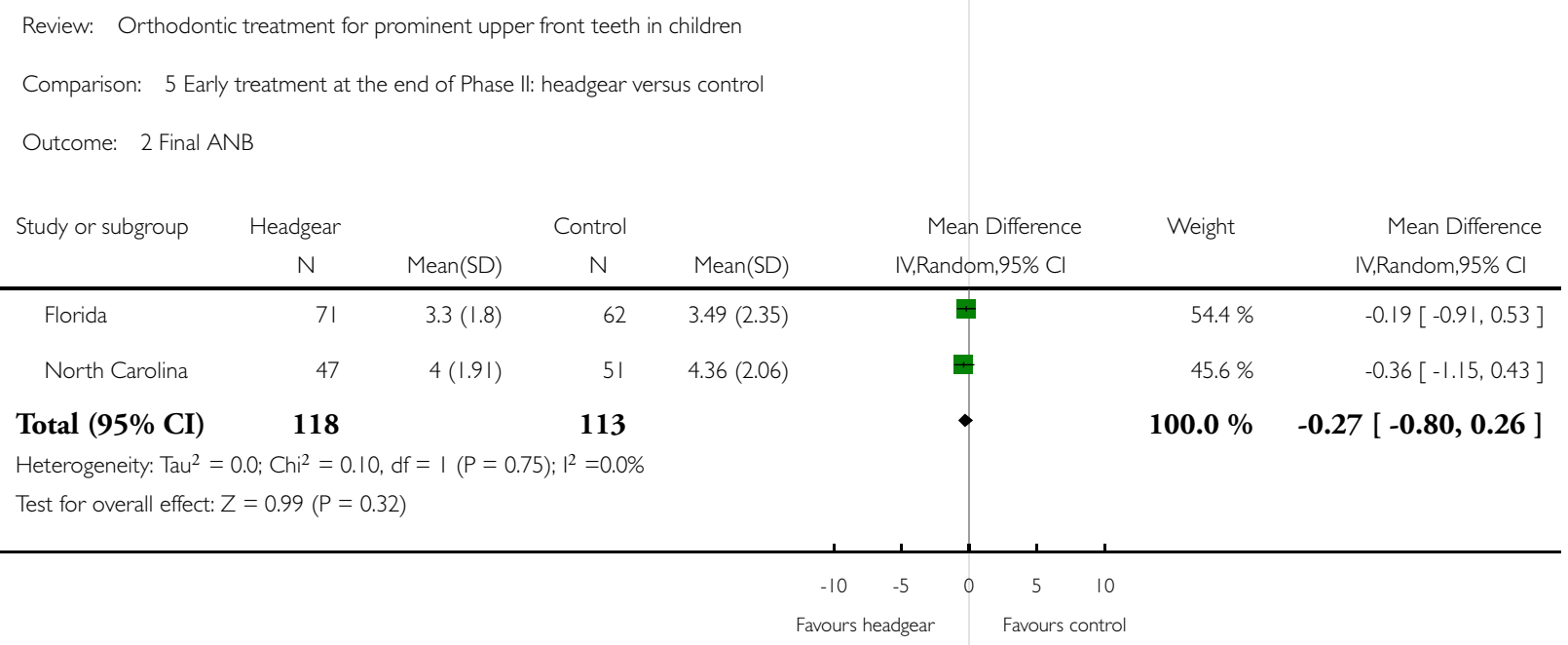


Analysis 5.3. Comparison 5 Early treatment at the end of Phase II: headgear versus control, Outcome 3 PAR score.

Review: Orthodontic treatment for prominent upper front teeth in children

Comparison: 5 Early treatment at the end of Phase Il: headgear versus control

Outcome: 3 PAR score

\begin{tabular}{|c|c|c|c|c|c|c|c|}
\hline \multirow[t]{2}{*}{ Study or subgroup } & Headgear & \multicolumn{3}{|c|}{ Control } & \multirow{2}{*}{$\begin{array}{l}\text { Mean Difference } \\
\text { IV,Random,95\% Cl }\end{array}$} & \multirow[t]{2}{*}{ Weight } & \multirow{2}{*}{$\begin{array}{l}\text { Mean Difference } \\
\text { IV,Random,95\% Cl }\end{array}$} \\
\hline & $\mathrm{N}$ & Mean(SD) & $\mathrm{N}$ & Mean(SD) & & & \\
\hline Florida & 72 & $5.3(4.5)$ & 7 & $6(4.4)$ & \begin{tabular}{l|l}
+4 \\
4
\end{tabular} & $39.4 \%$ & $-0.70[-4.12,2.72]$ \\
\hline North Carolina & 47 & $7.2(5.7)$ & 51 & $9.3(8.1)$ & ? & $60.6 \%$ & $-2.10[-4.86,0.66]$ \\
\hline
\end{tabular}

Total (95\% CI) 119

Heterogeneity: $\mathrm{Tau}^{2}=0.0 ; \mathrm{Chi}^{2}=0.39, \mathrm{df}=\mathrm{I}(\mathrm{P}=0.53) ; \mathrm{I}^{2}=0.0 \%$

Test for overall effect: $Z=1.41(P=0.16)$

$100.0 \% \quad-1.55[-3.70,0.60]$

Analysis 5.4. Comparison 5 Early treatment at the end of Phase II: headgear versus control, Outcome 4 New incisal trauma during Phase II treatment.

Review: Orthodontic treatment for prominent upper front teeth in children

Comparison: 5 Early treatment at the end of Phase II: headgear versus control

Outcome: 4 New incisal trauma during Phase II treatment

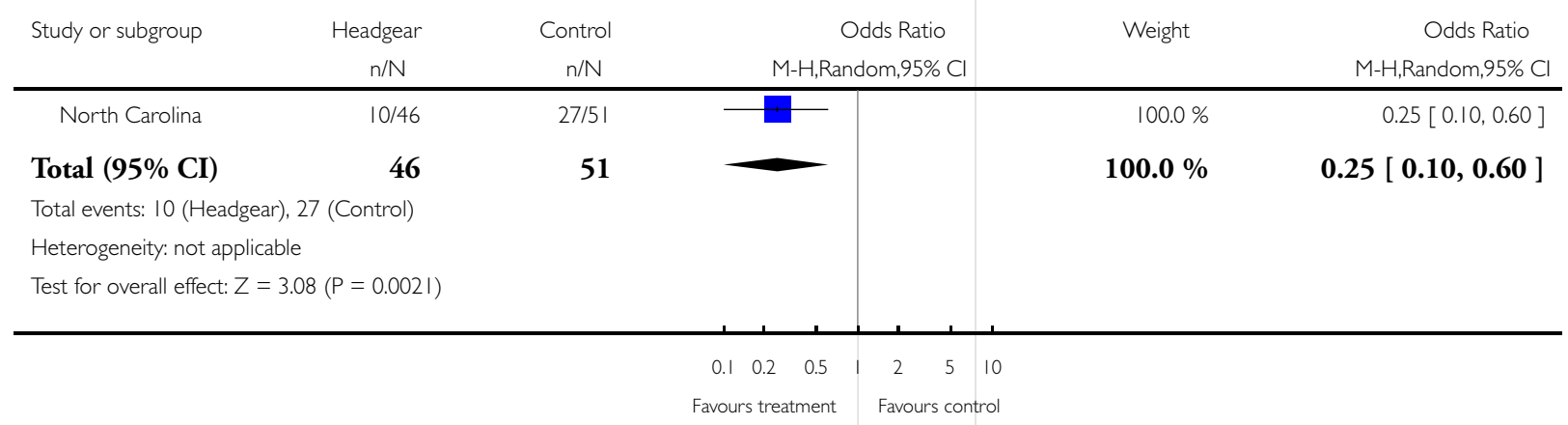


Analysis 6.I. Comparison 6 Early treatment at the end of Phase II: headgear versus functional, Outcome I Final overjet.

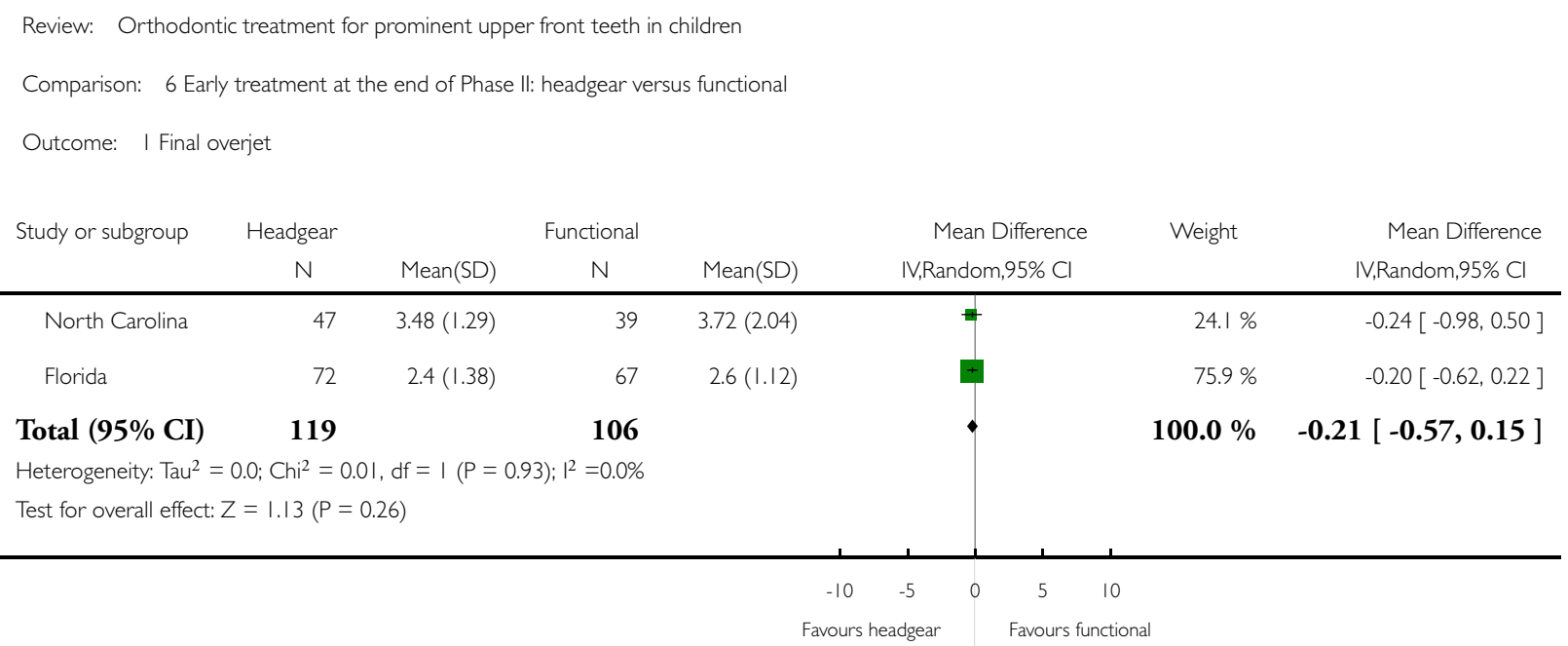

Analysis 6.2. Comparison 6 Early treatment at the end of Phase II: headgear versus functional, Outcome 2 Final ANB.

\begin{tabular}{|c|c|c|c|c|c|c|c|c|}
\hline \multicolumn{9}{|c|}{ Comparison: 6 Early treatment at the end of Phase ll: headgear versus functional } \\
\hline Outcome: 2 Final & & & & & & & & \\
\hline \multirow[t]{2}{*}{ Study or subgroup } & Headgear & & Functional & & & \multirow{2}{*}{$\begin{array}{r}\text { Mean Difference } \\
\text { IV,Random, } 95 \% \mathrm{Cl} \\
\end{array}$} & \multirow[t]{2}{*}{ Weight } & \multirow{2}{*}{$\begin{array}{l}\text { Mean Difference } \\
\text { IV,Random,95\% Cl }\end{array}$} \\
\hline & $\mathrm{N}$ & Mean(SD) & $\mathrm{N}$ & Mean(SD) & & & & \\
\hline North Carolina & 47 & $4(1.9)$ & 39 & $3.72(2.12)$ & & + & $40.2 \%$ & $0.28[-0.58,1.14]$ \\
\hline Florida & 71 & $3.3(1.8)$ & 65 & $3.7(1.9)$ & & ت & $59.8 \%$ & $-0.40[-1.02,0.22]$ \\
\hline Total (95\% CI) & 118 & & 104 & & & $\bullet$ & $100.0 \%$ & $-0.13[-0.78,0.53]$ \\
\hline \multicolumn{9}{|c|}{ Heterogeneity: $\operatorname{Tau}^{2}=0.08 ; \mathrm{Chi}^{2}=1.58, \mathrm{df}=\mathrm{I}(\mathrm{P}=0.2 \mathrm{I}) ; \mathrm{I}^{2}=37 \%$} \\
\hline \multicolumn{9}{|c|}{ Test for overall effect: $Z=0.38(P=0.70)$} \\
\hline & & & & & -10 & -5 & 10 & \\
\hline & & & & & Evours & Favours func & nctional & \\
\hline
\end{tabular}


Analysis 6.3. Comparison 6 Early treatment at the end of Phase II: headgear versus functional, Outcome 3 PAR score.

Review: Orthodontic treatment for prominent upper front teeth in children

Comparison: 6 Early treatment at the end of Phase II: headgear versus functional

Outcome: 3 PAR score

\begin{tabular}{lcccccc} 
Study or subgroup & Headgear & & Functional & Mean Difference & Weight & Mean Difference \\
& $N$ & Mean(SD) & N & Mean(SD) & IV,Random,95\% Cl & $-0.70[-2.29,0.89]$ \\
\hline Florida & 72 & $5.3(4.5)$ & 66 & $6(5)$ & $-17.0 \%$ & $23.0 \%$
\end{tabular}

Total (95\% CI) 119

Heterogeneity: $\mathrm{Tau}^{2}=0.0 ; \mathrm{Chi}^{2}=0.09, \mathrm{df}=\mathrm{I}(\mathrm{P}=0.77) ; \mathrm{I}^{2}=0.0 \%$

Test for overall effect: $Z=1.14(P=0.25)$

$100.0 \% \quad-0.81[-2.21,0.58]$

$\begin{array}{ccccc}-10 & -5 & 0 & 5 & 10 \\ \text { Favours functional } & \text { Favours headgear } & \text { Far }\end{array}$

Analysis 6.4. Comparison 6 Early treatment at the end of Phase II: headgear versus functional, Outcome 4 New incisal trauma during Phase II treatment.

Review: Orthodontic treatment for prominent upper front teeth in children

Comparison: 6 Early treatment at the end of Phase II: headgear versus functional

Outcome: 4 New incisal trauma during Phase II treatment

\begin{tabular}{|c|c|c|c|c|c|c|}
\hline \multirow[t]{2}{*}{ Study or subgroup } & Headgear & Functional & \multicolumn{2}{|r|}{ Odds Ratio } & \multirow[t]{2}{*}{ Weight } & \multirow{2}{*}{$\begin{array}{c}\text { Odds Ratio } \\
\mathrm{M}-\mathrm{H}, \text { Random,95\% Cl}\end{array}$} \\
\hline & $\mathrm{n} / \mathrm{N}$ & $\mathrm{n} / \mathrm{N}$ & & M-H,Random,95\% Cl & & \\
\hline North Carolina & $10 / 46$ & $13 / 42$ & & + & $100.0 \%$ & $0.62[0.24,1.62]$ \\
\hline Total (95\% CI) & 46 & 42 & & & $100.0 \%$ & $0.62[0.24,1.62]$ \\
\hline \multicolumn{7}{|c|}{ Total events: I0 (Headgear), I 3 (Functional) } \\
\hline \multicolumn{7}{|c|}{ Heterogeneity: not applicable } \\
\hline \multicolumn{7}{|c|}{ Test for overall effect: $Z=0.98(P=0.33)$} \\
\hline
\end{tabular}


Analysis 7.I. Comparison 7 Adolescent treatment: functional versus control, Outcome I Final overjet. Review: Orthodontic treatment for prominent upper front teeth in children

Comparison: 7 Adolescent treatment: functional versus control

Outcome: I Final overjet

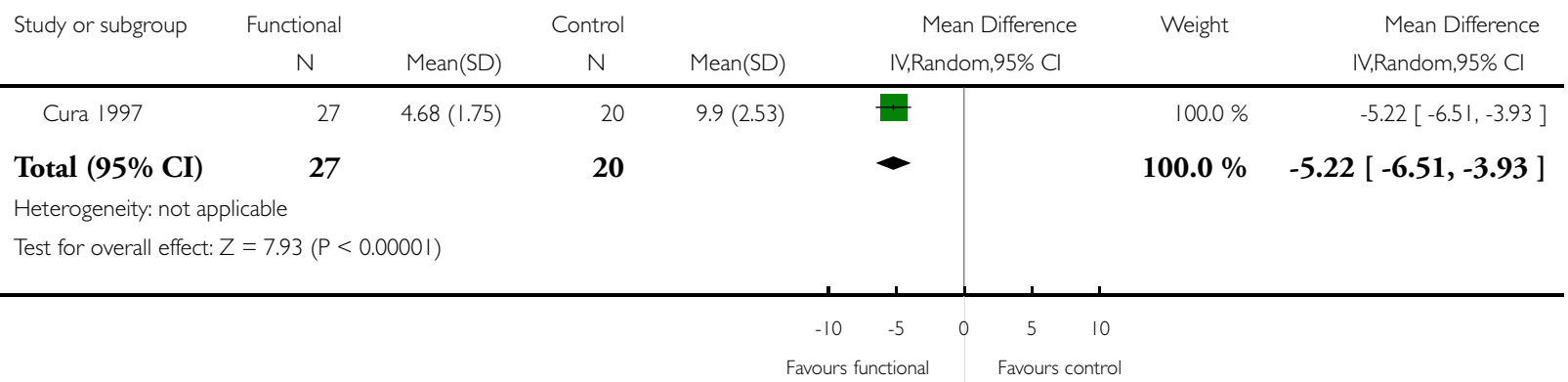

Analysis 7.2. Comparison 7 Adolescent treatment: functional versus control, Outcome 2 Final ANB.

Review: Orthodontic treatment for prominent upper front teeth in children

Comparison: 7 Adolescent treatment: functional versus control

Outcome: 2 Final ANB

\begin{tabular}{|c|c|c|c|c|c|c|c|}
\hline \multirow{2}{*}{ Study or subgroup } & \multirow{2}{*}{$\begin{array}{c}\text { Functional } \\
\mathrm{N}\end{array}$} & \multicolumn{3}{|c|}{ Control } & \multirow{2}{*}{$\begin{array}{l}\text { Mean Difference } \\
\text { IV,Random,95\% Cl }\end{array}$} & \multirow[t]{2}{*}{ Weight } & \multirow{2}{*}{$\begin{array}{l}\text { Mean Difference } \\
\text { IV,Random,95\% Cl }\end{array}$} \\
\hline & & Mean(SD) & $\mathrm{N}$ & Mean(SD) & & & \\
\hline Cura 1997 & 27 & $4.85(2.21)$ & 20 & $6.5(2)$ & $\because$ & $38.2 \%$ & $-1.65[-2.86,-0.44]$ \\
\hline Mao 1997 & 26 & $3.88(1.5 \mathrm{I})$ & 26 & $6.53(1.23)$ & 품 & $61.8 \%$ & $-2.65[-3.40,-1.90]$ \\
\hline
\end{tabular}

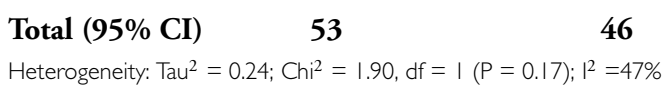

Test for overall effect: $Z=4.67(P<0.0000$ I $)$

$\begin{array}{ccccc}-10 & -5 & 0 & 5 & 10 \\ \text { Favours functional } & & \text { Favours control }\end{array}$


Analysis 8.I. Comparison 8 Adolescent treatment: Twin Block versus other functional appliances, Outcome I Final ANB.

Review: Orthodontic treatment for prominent upper front teeth in children

Comparison: 8 Adolescent treatment: Twin Block versus other functional appliances

Outcome: I Final ANB

\begin{tabular}{|c|c|c|c|c|c|c|c|}
\hline \multirow{2}{*}{ Study or subgroup } & \multirow{2}{*}{$\begin{array}{c}\text { Twin Block } \\
\text { N }\end{array}$} & \multicolumn{3}{|c|}{ Other functional } & \multirow{2}{*}{$\begin{array}{l}\text { Mean Difference } \\
\text { IV,Random,95\% Cl }\end{array}$} & \multirow[t]{2}{*}{ Weight } & \multirow{2}{*}{$\begin{array}{l}\text { Mean Difference } \\
\text { IV,Random,95\% Cl }\end{array}$} \\
\hline & & Mean(SD) & $\mathrm{N}$ & Mean(SD) & & & \\
\hline London & 16 & $4.8(1.8)$ & 18 & $5(2.4)$ & $\rightarrow$ & $20.5 \%$ & $-0.20[-1.62,1.22]$ \\
\hline UK $(||-\mid 4)$ & 52 & $3.8(2)$ & 69 & $4.6(2)$ & + & $79.5 \%$ & $-0.80[-1.52,-0.08]$ \\
\hline
\end{tabular}

Total (95\% CI) $\quad 68 \quad 87$

Heterogeneity: Tau $^{2}=0.0 ; \mathrm{Chi}^{2}=0.55, \mathrm{df}=\mathrm{I}(\mathrm{P}=0.46) ; \mathrm{I}^{2}=0.0 \%$

Test for overall effect: $Z=2.07(P=0.039)$

$100.0 \%-0.68[-1.32,-0.04]$

Analysis 8.2. Comparison 8 Adolescent treatment: Twin Block versus other functional appliances, Outcome 2 Final overjet.

Review: Orthodontic treatment for prominent upper front teeth in children

Comparison: 8 Adolescent treatment: Twin Block versus other functional appliances

Outcome: 2 Final overjet

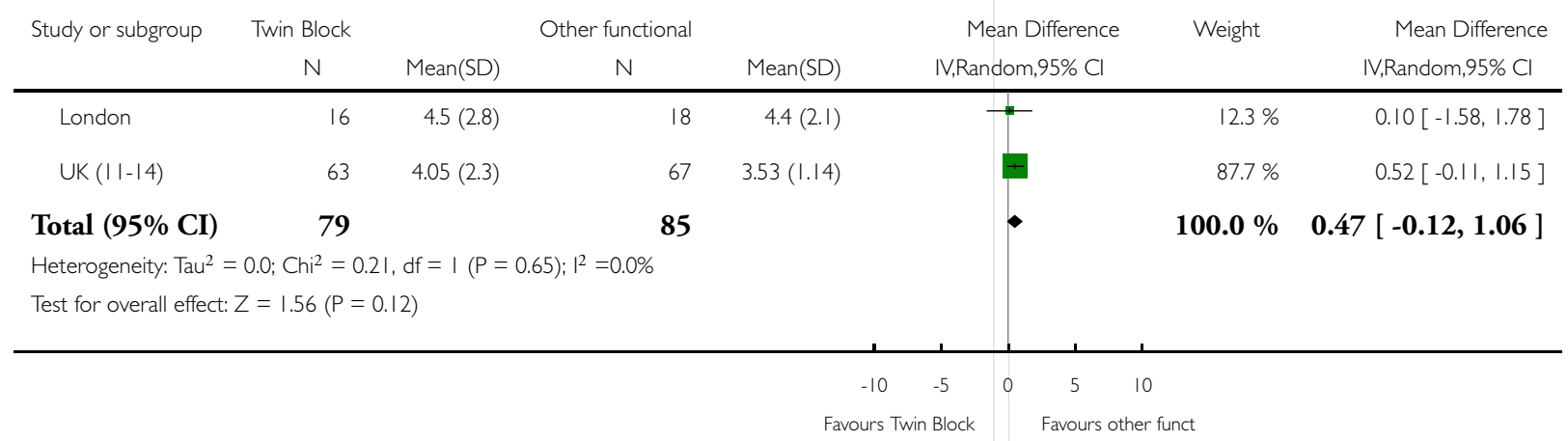




\section{A P P E N D I CES}

\section{Appendix I. MEDLINE search strategy}

\#1 MALOCCLUSION-ANGLE-CLASS-II (ME)

\#2 (“Class II" AND ((Angle OR Angle's) OR malocclusion OR bite)

\#3 (Explode) ORTHODONTIC-APPLIANCES-FUNCTIONAL (ME)

\#4 (Explode) ORTHODONTIC-APPLIANCES-REMOVABLE (ME)

\#5 "Frankel" OR "Twin*block" OR "Fixed appliance"

\#6 ((Extraoral OR "extra oral" OR extra-oral) AND appliance*)

\#7 ("growth modif*" AND (jaw OR maxilla* OR mandible)

\#8 ("head gear" OR headgear)

\#9 ((two-phase (treatment OR therapy)) AND (orthodontic* OR malocclusion))

\#10 ((orthopedic* OR orthopaedic*) AND (dental OR orthodontic* OR facial))

\#11 \#1 OR \#2

\#12 \#3 OR \#4 OR \#5 OR \#6 OR \#7 OR \#8 OR \#9 OR \#10

\#13 \#11 AND \#12

\section{WHAT'S NEW}

Last assessed as up-to-date: 14 May 2007.

23 June 2008 Amended Converted to new review format.

\section{H I S T O R Y}

Protocol first published: Issue 1, 2002

Review first published: Issue 3, 2007

\section{CONTRIBUTIONSOFAUTHORS}

The review was conceived by Jayne Harrison (JH), Kevin O’Brien (KOB) and Bill Shaw (Cochrane Oral Health Group). Previous work, that was the foundation of current study, was undertaken by JH and KOB. The protocol was written by JH, Helen Worthington (HW) and KOB.

The review was co-ordinated by JH and KOB. Sylvia Bickley (Cochrane Oral Health Group) developed the search strategy and undertook the electronic searches. JH undertook the handsearching. JH and $\mathrm{KOB}$ screened the search results and retrieved papers, appraised the quality of the papers and extracted data from them. HW checked the data extraction, analysed the data and assisted in the interpretation of the data. JH, KOB and HW wrote the review. 


\section{DECLARATIONS OF INTEREST}

Kevin O'Brien was involved in acquiring funding, running and reporting of the UK (11-14) and UK (Mixed) trials.

\section{SOURCES OF SUPPORT}

\section{Internal sources}

- The Royal Liverpool and Broadgreen University Hospitals NHS Trust, UK.

- The University of Manchester, UK.

- Cochrane Oral Health Group, UK.

\section{External sources}

- NHS National Primary Dental Care R\&D programme PCD97-303, UK.

\section{N DEX TERMS}

\section{Medical Subject Headings (MeSH)}

Adolescent; Age Factors; Malocclusion, Angle Class II [*therapy]; Orthodontic Appliances, Functional; Orthodontic Retainers; Orthodontics, Corrective [ ${ }^{*}$ methods]; Randomized Controlled Trials as Topic; Treatment Outcome

\section{MeSH check words}

Child; Humans 